\title{
In search of an ice core signal to differentiate between source-driven and sink-driven changes in atmospheric methane
}

\author{
J. G. Levine, ${ }^{1}$ E. W. Wolff, ${ }^{1}$ A. E. Jones, ${ }^{1}$ M. A. Hutterli, ${ }^{1,2}$ O. Wild, ${ }^{3}$ G. D. Carver, ${ }^{4,5}$ \\ and J. A. Pyle ${ }^{4,5}$
}

Received 6 August 2010; revised 3 December 2010; accepted 29 December 2010; published 11 March 2011.

[1] The concentration of atmospheric methane increased from around $360 \mathrm{ppbv}$ at the last glacial maximum ( $\sim 20 \mathrm{ka}$ before present) to about $700 \mathrm{ppbv}$ in the pre-industrial era ( 200 years before present). The sources and/or sinks of methane must therefore have changed during this period; however, the relative sizes of the source- and sink-driven changes in methane concentration remain uncertain. We take the first "bottom-up" approach to identifying any chemical signals preserved in the ice record that could help us to determine these. Using an atmospheric chemistry-transport model, we explore the effects of source- and sink-driven changes in methane on a wide range of chemical species in the Antarctic boundary layer. Though we identify several potentially useful atmospheric signals, a simple and robust constraint on the sizes of the source- and sink-driven changes cannot be readily identified, owing to their preservation in the ice, limitations to the information they hold, and/or ambiguity surrounding their interpretation. This includes the mass-independent fractionation of oxygen isotopes in sulfates, and the concentration of formaldehyde, in which there has been considerable interest. Our exploration is confined to a domain in which $\mathrm{NO}_{\mathrm{x}}$ emissions and climate remain constant. However, given the uncertainties associated with the changes in these factors, we would anticipate that their inclusion would make it harder still to identify a robust signal. Finally, though formaldehyde cannot provide this, we propose how it might be used to synchronize the gas- and aqueous-phase Antarctic ice records and thus determine the relative phasing of glacial-interglacial changes in Southern Hemisphere $\mathrm{CO}_{2}$ and temperature.

Citation: Levine, J. G., E. W. Wolff, A. E. Jones, M. A. Hutterli, O. Wild, G. D. Carver, and J. A. Pyle (2011), In search of an ice core signal to differentiate between source-driven and sink-driven changes in atmospheric methane, J. Geophys. Res., 116, D05305, doi:10.1029/2010JD014878.

\section{Introduction}

[2] The concentration of atmospheric methane trapped in Antarctic ice shows large variations over the last 800,000 years that appear to track changes in temperature on orbital, and shorter, time scales [Jouzel et al., 2007; Loulergue et al., 2008]; see, for example, Chappellaz et al. [1993a] for details of the phase relationship between changes in methane and climate in Greenland. This study focuses on the increase in methane from around $360 \mathrm{ppbv}$ at the last glacial maximum (LGM; 20 ka before present) to approximately 700 ppbv in the pre-industrial era (PI; $\sim 200$ years before present). Fun-

\footnotetext{
${ }^{1}$ British Antarctic Survey, Cambridge, UK

${ }^{2}$ Now at TOFWERK AG, Thun, Switzerland.

${ }^{3}$ Lancaster Environment Centre, University of Lancaster, Lancaster, UK.

${ }^{4}$ Centre for Atmospheric Science, Department of Chemistry, University of Cambridge, Cambridge, UK.

${ }^{5}$ National Centre for Atmospheric Science, University of Cambridge, Cambridge, UK
}

Copyright 2011 by the American Geophysical Union. 0148-0227/11/2010JD014878 damentally, the increase must have resulted from a change in methane sources, such as emissions from wetlands-the largest natural source of methane-and/or a change in methane sinks, the dominant one being oxidation by the hydroxyl radical $(\mathrm{OH})$, but the balance between these changes remains uncertain. Our aim is to identify any atmospheric chemical signals that could be used to differentiate between changes in methane emissions and changes in $\mathrm{OH}$, and assess the likelihood they are preserved in Antarctic ice.

[3] Estimates of the changes in methane emissions between the LGM and the PI vary, with much of the discussion focusing on the change in emissions from wetlands. Based on a reconstruction of vegetation, Chappellaz et al. [1993b] estimated that wetland emissions increased by $80 \%$ between the LGM and the PI, underpinning a $46 \%$ increase in total methane emissions that could explain around half the $94 \%$ increase in methane concentration (from 360 to $700 \mathrm{ppbv}$ ). Bottom-up studies employing dynamic global vegetation models, on the other hand, have calculated much smaller increases in wetland emissions, ranging from effectively no change [Kaplan et al., 2006] to an increase of $36 \%$ [Valdes et al., 2005], and consequently 
more modest increases in total methane emissions, of $19 \%$ and $31 \%$, respectively. Recent calculations by Weber et al. [2010], based on climate simulations from the second phase of the Paleoclimate Modeling Intercomparison Project (PMIP2) [Braconnot et al., 2007], suggest wetland emissions increased by between 54 and $72 \%$, and highlight the uncertainty that remains in the size of the source-driven component of the LGM-PI change in methane concentration.

[4] The estimated changes in methane emissions cited above suggest changes in methane sources alone cannot fully account for the LGM-PI change in methane, and a significant fraction of this must have been sink-driven (i.e., the result of an increase in the atmospheric lifetime of methane). Valdes et al. [2005] and Kaplan et al. [2006] showed how the concentration of $\mathrm{OH}$ could have decreased, and hence the lifetime of methane increased, as a result of an increase in the amount of nonmethane volatile organic compounds (NMVOCs) emitted from vegetation. An increase in NMVOC emissions between the LGM and the PI is consistent with vegetation reconstructions [see, e.g., Adams et al., 2001] and model studies of the influence that rising temperatures have on vegetation [e.g., Lathière et al., 2005]. However, the size of this increase remains uncertain [see, e.g., Arneth et al., 2007], since some laboratory studies have identified a reduction in NMVOC emissions as the concentration of $\mathrm{CO}_{2}$ to which vegetation is exposed is increased [e.g., Wilkinson et al., 2009], and the concentration of $\mathrm{CO}_{2}$ rose between the LGM and the PI [Monnin et al., 2001]. The possible 'recycling' of $\mathrm{OH}$ consumed in isoprene oxidation [Lelieveld et al., 2008] adds to the uncertainty in the influence NMVOC emissions had on $\mathrm{OH}$ and, hence, the size of the sink-driven component of the change in methane concentration.

[5] Changes in the amount of nitrogen oxides $\left(\mathrm{NO}_{\mathrm{x}}=\mathrm{NO}+\right.$ $\mathrm{NO}_{2}$ ) emitted from climate-sensitive sources, such as soils, lightning and biomass burning, could have also affected the lifetime of methane with respect to $\mathrm{OH}$. All else being equal, we would expect an increase (decrease) in $\mathrm{NO}_{\mathrm{x}}$ emissions to have led to an increase (decrease) in the concentration of ozone $\left(\mathrm{O}_{3}\right)$, and hence an increase (decrease) in the concentration of $\mathrm{OH}$, since $\mathrm{OH}$ is formed from the reaction between excited $\mathrm{O}\left({ }^{1} \mathrm{D}\right)$ oxygen atoms (derived from $\left.\mathrm{O}_{3}\right)$ and water vapor. Valdes et al. [2005] estimated that $\mathrm{NO}_{\mathrm{x}}$ emissions from lightning increased from 3.4 to $4.2 \mathrm{Tg} \mathrm{N} \mathrm{yr}^{-1}$, while those from soils decreased from 5.7 to 5.1 $\mathrm{Tg} \mathrm{N} \mathrm{yr}^{-1}$, leading to an overall $6 \%$ reduction in the lifetime of methane in the PI, relative to the LGM. However, their estimates of the lightning and soil source strengths are subject to large uncertainties; the emissions from lightning, to which the lifetime of methane is especially sensitive, are uncertain in the present, never mind the past [Wild, 2007]. It is also unclear how $\mathrm{NO}_{\mathrm{x}}$ emissions from biomass burning changed during this period. Calculations by Thonicke et al. [2005] using a dynamic global vegetation model with an embedded fire module suggested these could have decreased in the tropics, and thus contributed to an increase in the lifetime of methane. However, based on a suite of Monte Carlo calculations, Fischer et al. [2008] concluded that the amount of biomass burning was roughly constant between the LGM and the PI, and a global synthesis of charcoal records by Power et al. [2008] identified the last glacial period (16-21 ka before present) as the period of least biomass burning in the last $21 \mathrm{kyr}$, and hence an increase in biomass burning emissions from the LGM to the PI.

[6] The change in climate itself would have also affected the lifetime of methane. Contrary to the increase that could help to explain the observed increase in methane concentration, the increase in temperatures, and hence humidities, would have tended to reduce the lifetime of methane by increasing the (temperature-dependent) rate of reaction between $\mathrm{OH}$ and methane, and increasing the concentration of OH. Martinerie et al. [1995] estimated that the increase in humidity would have led to a $6 \%$ reduction in the lifetime of methane, while Valdes et al. [2005] estimated that this, together with the increased rate of reaction between $\mathrm{OH}$ and methane, would have led to a reduction of $14 \%$. These estimates, however, are subject to significant uncertainties in the changes in temperature between the LGM and the PI [e.g., Braconnot et al., 2007], particularly in the tropics where roughly three quarters of methane oxidation occurs [see, e.g., Lawrence et al., 2001; Labrador et al., 2004]. Proxy data collated and analyzed within the Multiproxy Approach for the Reconstruction of the Glacial Ocean Surface Project [MARGO Project Members, 2009] show an average sea surface-temperature warming between $15^{\circ} \mathrm{N}$ and $15^{\circ} \mathrm{S}$ of $1.7( \pm 1.0)^{\circ} \mathrm{C}$ between the LGM and the PI, and the large, relative uncertainty in this figure (almost 60\%) is echoed in the wide range of warmings exhibited by state-of-the-art climate models, from 1.0 to $2.4^{\circ} \mathrm{C}$ [Otto-Bliesner et al., 2009]. What is not in question, is that the warming climate would have tended to reduce the lifetime of methane. The most likely explanation identified in the literature for a net increase in methane lifetime from the LGM to the PI, which would help to explain the increase in methane concentration, depends upon an increase in NMVOC emissions (discussed above).

[7] Previous observational studies suggesting the concentration of $\mathrm{OH}$ has changed in the past have largely taken a 'top-down' approach, attributing changes in the concentration, or isotopic composition, of atmospheric constituents trapped or dissolved in polar ice to changes in oxidizing capacity. A variety of chemical signals with which to identify changes in $\mathrm{OH}$ have thus been proposed, including: the concentration of formaldehyde [Staffelbach et al., 1991]; the concentrations of hydrogen peroxide and methylperoxide [Gillett et al., 2000]; and the mass-independent fractionation of oxygen isotopes in sulfates [Savarino et al., 2003]. Studies taking a top-down approach implicitly assume the concentration, or isotopic composition, of a constituent trapped or dissolved in the ice bears some relation to the concentration, or isotopic composition, of that constituent in the boundary layer during the period in which gases could freely exchange between the atmosphere and the then uncompacted snow, or 'firn.' In the case of methane, its concentration in air trapped in the ice is almost identical to its concentration in the atmosphere. However, the relationship can be considerably more complicated, as is the case for formaldehyde, the concentration of which in ice is modified during and postdeposition [Hutterli et al., 1999, 2002].

[8] In contrast to previous studies, we take a 'bottom-up' approach, using the Cambridge parallelised-Tropospheric Offline Model of Chemistry and Transport ( $p$-TOMCAT), which is described in section 2.1, to explore changes in the chemical composition of the Antarctic boundary layer 
accompanying source- and sink-driven changes in methane. We carry out six experiments: a PI model run, which is described in section 2.2, and five sensitivity experiments derived from this, which are described in section 2.3. Note that we are not trying to simulate the LGM-PI change in methane. Instead, these are highly idealized experiments, exploring extreme scenarios, in an effort to identify any chemical signal (a chemical species, or combination of species, among those included in p-TOMCAT) that shows potential to constrain the cause(s) of this change. We examine the results of these experiments in sections 3.1 and 3.2. In sections 3.3 and 3.4 , we briefly assess the sensitivity of our results to interannual variations in meteorology and the definition of the Antarctic boundary layer, respectively, before discussing in section 4 the preservation in Antarctic ice of those signals which show some potential, and issues surrounding their interpretation.

\section{Method}

\subsection{The Cambridge p-TOMCAT Model}

[9] For the purposes of this study, we use the Cambridge p-TOMCAT model of tropospheric chemistry and transport, which has been used in a variety of recent studies [Köhler et al., 2008; Yang et al., 2008; Cook et al., 2007; and Levine et al., 2007]. This is a three-dimensional Eulerian model driven by wind, temperature and humidity fields taken from the operational analyses of the European Centre for Medium-range Weather Forecasts (ECMWF). Here, the model is run at a horizontal resolution of approximately $2.8^{\circ} \times 2.8^{\circ}$ on 31 levels, which stretch from the surface to $10 \mathrm{hPa}$ with a typical spacing of about $100 \mathrm{~m}$ in the boundary layer and $1-1.5 \mathrm{~km}$ in the vicinity of the tropopause. Tracer advection is calculated with the second-order moments advection scheme of Prather [1986], as implemented by Chipperfield [1996]. Transport in the horizontal is driven directly by the ECMWF winds while vertical transport is calculated based on the convergence/divergence of winds in the horizontal. Strong convergence also triggers convection, which is simulated using the mass flux parameterization of Tiedtke [1989]. The model also contains a nonlocal vertical diffusion scheme for the boundary layer based on the parameterization of Holtslag and Boville [1993]; see Wang et al. [1999] for details of its implementation.

[10] The model chemistry includes 52 chemical species and 174 reactions, which describe the gas-phase $\mathrm{HO}_{\mathrm{x}} / \mathrm{NO}_{\mathrm{x}}$ chemistries of methane, ethane, propane and isoprene, the latter according to the Mainz Isoprene Mechanism [Pöschl et al., 2000]; the model also includes a simple ethene-like tracer, which is simply emitted, and removed by $\mathrm{OH}$. The chemistry scheme is of medium complexity, comparable with the schemes employed in other tropospheric chemistrytransport models, such as the troposphere-only version of the UK Chemistry Aerosol Community Model currently under development (see http://www.ukca.ac.uk), and is suitable for global integrations spanning years to decades. The bimolecular and termolecular reaction-rate coefficients (last updated in March 2005) are taken from the International Union of Pure and Applied Chemistry (R. Atkinson et al., Summary of Evaluated Kinetic and Photochemical Data for Atmospheric Chemistry, 2005, http://www.iupac-kinetic.ch. cam.ac.uk) (hereinafter Atkinson et al., http://www.iupac- kinetic.ch.cam.ac.uk, 2005) and the Master Chemical Mechanism (see http://mcm.leeds.ac.uk/MCM/home.htt), while the photolysis rates are calculated offline using the Cambridge 2D model [Law and Pyle, 1993], which is also used to provide top-boundary conditions for ozone and $\mathrm{NO}_{\mathrm{y}}$. The concentrations of species are integrated forward in time using the ASAD code of Carver et al. [1997] and the IMPACT time integrator of Carver and Stott [2000]. The wet deposition of soluble species is linked to the parameterization of convection (and large-scale rainfall) according to Walton et al. [1988]. The dry deposition of species at the surface is calculated using prescribed $1 \mathrm{~m}$ deposition velocities [Valentin, 1990], extrapolated to the center of each grid box in the lowest level of the model according to Berntsen and Isaksen [1997]. For more details on the implementation and validation of the wet and dry deposition schemes, see Giannakopoulos et al. [1999].

[11] The model does not include halogen chemistry (including the oxidation of methane initiated by atomic chlorine), snow photochemistry or the loss of methane to soils. Platt et al. [2004] estimate that atomic chlorine is responsible for about $3 \%$ of global methane loss. We would not expect the inclusion of an additional sink of this size to alter our findings significantly, particularly those of a qualitative nature. Snow photochemistry will affect $\mathrm{OH}$ in the boundary layer in snow covered regions [see, e.g., Grannas et al., 2007]. We would have to include this if our aim was to reproduce absolute $\mathrm{OH}$ concentrations measured in such regions, but it should not have much effect on the global oxidizing capacity. Last, the loss of methane to soils is omitted on the basis that it accounts for only $5-10 \%$ of global methane loss, which is small compared to the uncertainty in the PI emissions of methane implemented in the model [Valdes et al., 2005]; see section 2.2.

\subsection{The PI Model Run}

[12] For the purposes of this experiment, we have implemented as far as practically possible the same PI emissions in the Cambridge p-TOMCAT model as Valdes et al. [2005] used in the STOCHEM atmospheric chemistrytransport model. The emissions, summarized in Table 1, include: seasonally varying emissions of nitrogen dioxide $\left(\mathrm{NO}_{2}\right)$, methane $\left(\mathrm{CH}_{4}\right)$, carbon monoxide $(\mathrm{CO})$, ethane $\left(\mathrm{C}_{2} \mathrm{H}_{6}\right)$, propane $\left(\mathrm{C}_{3} \mathrm{H}_{8}\right)$, acetone $\left(\mathrm{CH}_{3} \mathrm{COCH}_{3}\right)$, isoprene $\left(\mathrm{C}_{5} \mathrm{H}_{8}\right)$ and ethene $\left(\mathrm{C}_{2} \mathrm{H}_{4}\right)$, in addition to constant emissions of formaldehyde ( $\mathrm{HCHO})$ and acetaldehyde $\left(\mathrm{CH}_{3} \mathrm{CHO}\right)$. Note that, unlike Valdes et al. [2005], we do not include emissions of butane, propene, methanol or $\alpha$-pinene, owing to the lack of these species in p-TOMCAT; hydrogen is not emitted but is included in the model as a constant field. Lightning emissions of $\mathrm{NO}_{2}$ in p-TOMCAT are coupled in time and space to the parameterization of convection [Stockwell et al., 1999], and are therefore unlikely to be distributed in the same way, either spatially or temporally, as the lightning emissions of NO in STOCHEM. We note, however, that the total amount of $\mathrm{NO}_{\mathrm{x}}$ emitted from lightning in $\mathrm{p}$-TOMCAT (normalized to $4.8 \mathrm{Tg} \mathrm{N} / \mathrm{yr}$ ) is not dissimilar to that in STOCHEM (4.2 Tg N/yr) [Valdes et al., 2005].

[13] Figure 1 illustrates the distributions of these emissions (excluding lightning emissions of $\mathrm{NO}_{\mathrm{x}}$ ), integrated over a year. The emissions of methane are dominated by 
Table 1. Trace Gas Emissions Used in the PI Model Run, Expressed in Terms of Molecular Mass (Tg) per Year ${ }^{\mathrm{a}}$

\begin{tabular}{|c|c|c|c|c|c|c|c|c|}
\hline Trace Gas & Biomass Burning & Oceans & Vegetation & Soil & Lightning & Wetlands & Termites & Total \\
\hline $\mathrm{NO}_{2}$ & 4.7 & - & - & 16.8 & 15.8 & - & - & 37.3 \\
\hline $\mathrm{CH}_{4}$ & 11.0 & 13.0 & - & - & - & 147.9 & 27.0 & 198.9 \\
\hline $\mathrm{CO}$ & 100.0 & 50.0 & 150.0 & - & - & - & - & 300.0 \\
\hline $\mathrm{C}_{2} \mathrm{H}_{6}$ & 0.7 & - & 3.5 & - & - & - & - & 4.2 \\
\hline $\mathrm{C}_{3} \mathrm{H}_{8}$ & 0.2 & 0.5 & 3.5 & - & - & - & - & 4.2 \\
\hline $\mathrm{CH}_{3} \mathrm{COCH}_{3}$ & 0.1 & - & 20.0 & - & - & - & - & 20.1 \\
\hline $\mathrm{C}_{5} \mathrm{H}_{8}$ & - & - & 673.7 & - & - & - & - & 673.7 \\
\hline $\mathrm{C}_{2} \mathrm{H}_{4}$ & 1.4 & - & 20.0 & - & - & - & - & 21.4 \\
\hline $\mathrm{HCHO}$ & 0.3 & - & - & - & - & - & - & 0.3 \\
\hline $\mathrm{CH}_{3} \mathrm{CHO}$ & 0.8 & - & - & - & - & - & - & 0.8 \\
\hline
\end{tabular}

${ }^{\mathrm{a}}$ Except for the emissions of $\mathrm{NO}_{2}$ from lightning, these emissions are as close as practically possible to those used by Valdes et al. [2005] in their study of the LGM-PI change in methane, using the STOCHEM chemistry-transport model; see section 2.2 for more details.

emissions from wetlands in equatorial South America and Indonesia, and to a lesser extent, Central Africa and South East Asia. The relatively small amounts of methane coming from the oceans, biomass burning and termites (see Table 1) account for its near-ubiquitous, low-level emissions elsewhere around the globe. The emissions of isoprene, which exert a strong influence on $\mathrm{OH}$ as a result of isoprene's short lifetime with respect to oxidation (Atkinson et al., http:// www.iupac-kinetic.ch.cam.ac.uk, 2005), are concentrated in equatorial regions, but also appreciable in the subtropics of both hemispheres. The remaining emissions categorized under 'vegetation' in Table 1 are all distributed in the same way as each other, mostly in the tropics and subtropics but with a significant contribution from midlatitudes, particularly in the Northern Hemisphere. This distribution closely resembles the distribution of acetone emissions, the latter being overwhelmingly dominated by emissions from vegetation (see Table 1).

[14] The PI model run (and each sensitivity experiment) follows a certain format. The model is first run to equilibrium using repeated meteorology from a single year (1997). At 'equilibrium,' neither the global burden of methane nor the annual mean concentration of methane in the Antarctic boundary layer (AntBL; defined to comprise all boxes in the lowest level of the model south of $70^{\circ} \mathrm{S}$ ) changes by more than $0.02 \%$ per year. The model is then run with meteorology from three further years (1998-2000) to explore interannual variability. These three years were chosen on the basis that they include contrasting phases of the El NiñoSouthern Oscillation (ENSO), a major contributor to interannual variations in the distributions of trace gases within the troposphere [e.g., Chandra et al., 1998; Ziemke and Chandra, 2003]; the Northern Hemisphere winters of 1997/1998 and 1998/1999 were El Niño and La Niña, respectively, while 2000 was less affected by the ENSO. The data gathered in these three years are then used to characterize the chemical composition of the AntBL. Note, we assume recent meteorological analyses adequately represent the meteorology of the PI.

\subsection{The Sensitivity Experiments}

[15] We carry out five sensitivity experiments, each starting from the PI model setup; these are schematically illustrated in Figure 2. The first two experiments, Sink 1 and Source 1, are designed to identify any chemical signal that responds in a substantially different manner to purely source-driven and purely sink-driven changes in methane (of the same size), making no assumptions about the cause (s) of the latter. In Source 1, we reduce the concentration of methane in the AntBL to roughly that which was present at the LGM by scaling down the emissions of methane (uniformly) by $45 \%$. In Sink 1 , we increase the production of $\mathrm{OH}$ by a factor of 2.5 to effect the same change in methane concentration. We do so by increasing the number of $\mathrm{OH}$ radicals produced as each excited oxygen atom, $\mathrm{O}\left({ }^{1} \mathrm{D}\right)$, reacts with a water molecule. This is simply a way of increasing the concentration of $\mathrm{OH}$ without making any assumptions about the cause of this increase, which would have chemical consequences. For example, if we were to instead increase the rate of this reaction, we would not only increase the rate of $\mathrm{OH}$ formation, but also the rate of $\mathrm{O}\left({ }^{1} \mathrm{D}\right)$ removal. The third and fourth experiments, Sink 2 and Source 2, are designed to assess whether there exists a signal capable of differentiating between source- and sink-driven changes in methane, when the latter are the result of changes in the amount of NMVOCs emitted from vegetation. In Sink 2, all emissions from vegetation (i.e., those categorized under 'vegetation' in Table 1) are switched off, leading to a substantial reduction in methane, but a smaller one than in Sink 1 or Source 1. The same reduction in methane is achieved in Source 2, as in Sink 2, by scaling down the emissions of methane by $17 \%$. In the fifth experiment, Sink+Source, we remove all emissions from vegetation (as in Sink 2) and scale down the emissions of methane by $31 \%$ to reduce the concentration of methane to that which was present at the LGM (as in Sink 1 and Source 1). By comparing the results to this experiment with those to Source 1, we can assess a signal's ability to differentiate between a purely sourcedriven change in methane, and one which is part sourcedriven, part sink-driven.

[16] Though we explore in Sink 1 the consequences of a change in $\mathrm{OH}$ generated in such as way as to make no assumptions about the cause(s) of this change, we do not explore changes in $\mathrm{OH}$ driven explicitly by changes in $\mathrm{NO}_{\mathrm{x}}$ emissions or climate, which would have influences on the atmospheric composition besides their effects on $\mathrm{OH}$, and presumably different ones to the changes in NMVOC emissions that we explore in Sink 2 and Sink+Source. As outlined in section 1, there are significant uncertainties associated with the changes in $\mathrm{NO}_{\mathrm{x}}$ emissions and climate between the LGM and the PI, and their influences on the oxidizing capacity were probably subsidiary to the influence 

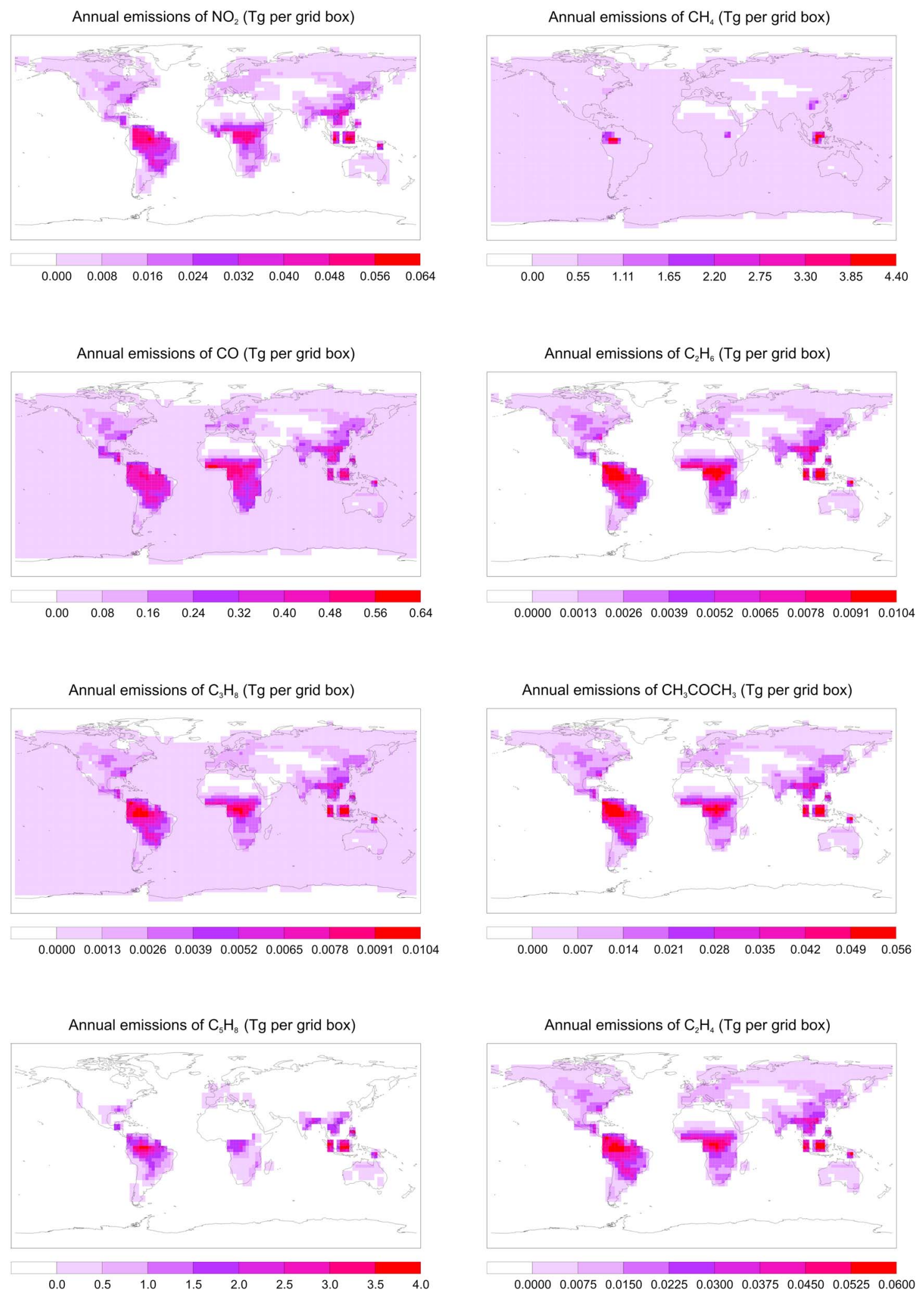

Figure 1. Distributions of the trace-gas emissions used in the PI model run, integrated over 1 year, expressed in terms of molecular mass (Tg) per grid box. They are as close as practically possible to those used by Valdes et al. [2005] in their study of the LGM-PI change in methane. NB The distribution of $\mathrm{NO}_{2}$ emissions excludes those from lightning; see section 2.2 for more details. 


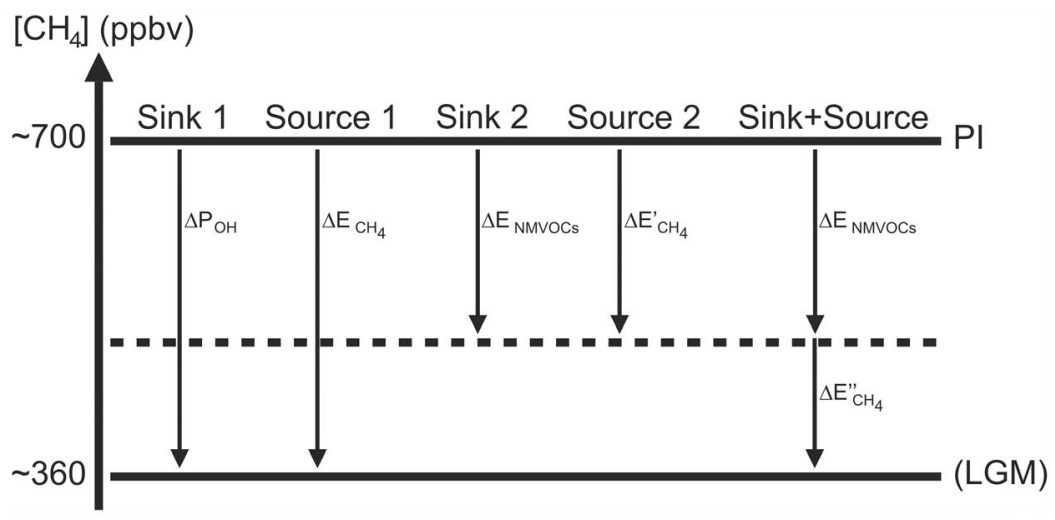

Figure 2. Schematic illustration of the five sensitivity experiments, described in section 2.3 , each starting from the PI model setup, described in section 2.2. In Source 1, the emissions of methane are reduced $\left(\Delta \mathrm{E}_{\mathrm{CH} 4}\right)$ so as to reduce the annual mean concentration of methane in the AntBL, $\left[\mathrm{CH}_{4}\right]$, to roughly that which characterized the $\mathrm{LGM}$, while the rate of $\mathrm{OH}$ production is increased $\left(\Delta \mathrm{P}_{\mathrm{OH}}\right)$ in Sink 1 to effect the same change in $\left[\mathrm{CH}_{4}\right]$. In Sink 2, all NMVOC emissions from vegetation are switched off $\left(\Delta \mathrm{E}_{\mathrm{NMVOCs}}\right)$, while the emissions of methane are reduced in Source $2\left(\Delta \mathrm{E}_{\mathrm{CH} 4}^{\prime}\right)$ to effect the same change in $\left[\mathrm{CH}_{4}\right]$. Finally, in Sink+Source, all NMVOC emissions from vegetation are switched off $\left(\Delta \mathrm{E}_{\mathrm{NMVOCs}}\right)$ and the emissions of methane are reduced $\left(\Delta \mathrm{E}^{\prime \prime}{ }_{\mathrm{CH}}\right)$ so as to reduce $\left[\mathrm{CH}_{4}\right]$ to roughly that which characterized the LGM, in line with Sink 1 and Source 1.

of changes in NMVOC emissions. Our approach is therefore to first try to find a signal capable of differentiating between source- and sink-driven changes in methane, subject to constant $\mathrm{NO}_{\mathrm{x}}$ emissions and climate, and only if we find such a signal (and believe it will be preserved in the ice record on the necessary time scales), explore whether it would prove robust to such changes.

\section{Results}

\subsection{Methane in the Antarctic (and Arctic) Boundary Layer}

[17] Figure 3 illustrates the concentrations of methane in the AntBL and the Arctic boundary layer (ArcBL; defined to comprise all boxes in the lowest level of the model north of $70^{\circ} \mathrm{N}$ ) that we calculate in the PI model run (Figure 3, top) and the five sensitivity experiments: Sink 1 , Source 1 and Sink+Source (Figure 3, bottom); Sink 2 and Source 2 (Figure 3, middle). In each case, the data correspond to the last three years of the model's run to equilibrium, using repeated 1997 meteorology, and the subsequent three years employing meteorology from 1998 to 2000.

[18] The PI model run (Figure 3, top) yields methane concentrations of 705-720 ppbv in the AntBL and 740 $755 \mathrm{ppbv}$ in the ArcBL, amounting to annual mean concentrations, averaged over 1998-2000, of $709 \mathrm{ppbv}$ and 744 ppbv, respectively. (From here on, all annual mean concentrations refer to averages over 1998-2000.) There is thus an average interhemispheric gradient of $35 \mathrm{ppbv}$, which arises as a result of a bias in the distribution of methane sources toward the Northern Hemisphere. This compares well with the average interhemispheric gradient of $35(+/-7)$ ppbv evident from high-resolution measurements between 0.25 and $1 \mathrm{ka}$ before present [Chappellaz et al., 1997]. In both the AntBL and the ArcBL, the concentration of methane exhibits an annual cycle, between a maximum in local spring and a minimum in local autumn, with a peak-to-peak amplitude of roughly $10 \mathrm{ppbv}$. This cycle reflects seasonal variations in the strength of methane emissions. Note that almost identical cycles are calculated in the last three years of the run to equilibrium $(3 \times 1997)$, confirming the model had indeed reached equilibrium before it was run with 1998-2000 meteorology. In the latter three years, the concentrations of methane show some interannual variability but no obvious trend; we note that the influence of interannual variations in meteorology on the concentration of methane has previously been explored by Warwick et al. [2002].

[19] The annual mean concentration of methane in the AntBL is reduced to around $340 \mathrm{ppbv}$ in Sink 1, Source 1 and Sink+Source (Figure 3, bottom). Recall, the aim in these experiments was to reduce the concentration of methane in this region to roughly that which characterized the LGM $(\sim 360 \mathrm{ppbv})$. However, the concentration of methane in the ArcBL is reduced to different extents in these experiments: to $375 \mathrm{ppbv}$ in Sink 1 and around $360 \mathrm{ppbv}$ in Source 1 and Sink+Source. It follows that, relative to the PI, the interhemispheric gradient remains unchanged in Sink 1 but is reduced in Source 1 and Sink+Source to around $20 \mathrm{ppbv-a}$ reduction of $43 \%$. It would therefore appear that, in Source 1, the interhemispheric gradient scales linearly with the amount of methane emitted, the latter being reduced by $45 \%$ relative to the PI. However, this scaling results from the way in which the emissions are reduced; by scaling the emissions uniformly, we do not change their geographical distribution. In reality, the reduction in methane emissions occurred mostly in the northern mid and high latitudes [e.g., Chappellaz et al., 1993b; Kaplan, 2002], and measurements at the LGM (16.7-20.3 ka before present) reveal an interhemispheric gradient of only a few ppbv [Dällenbach et al., 2000].

[20] In Sink 2 (Figure 3, middle), switching off all emissions from vegetation reduces the annual mean concentration of methane in the AntBL to 554 ppbv. This reduction 


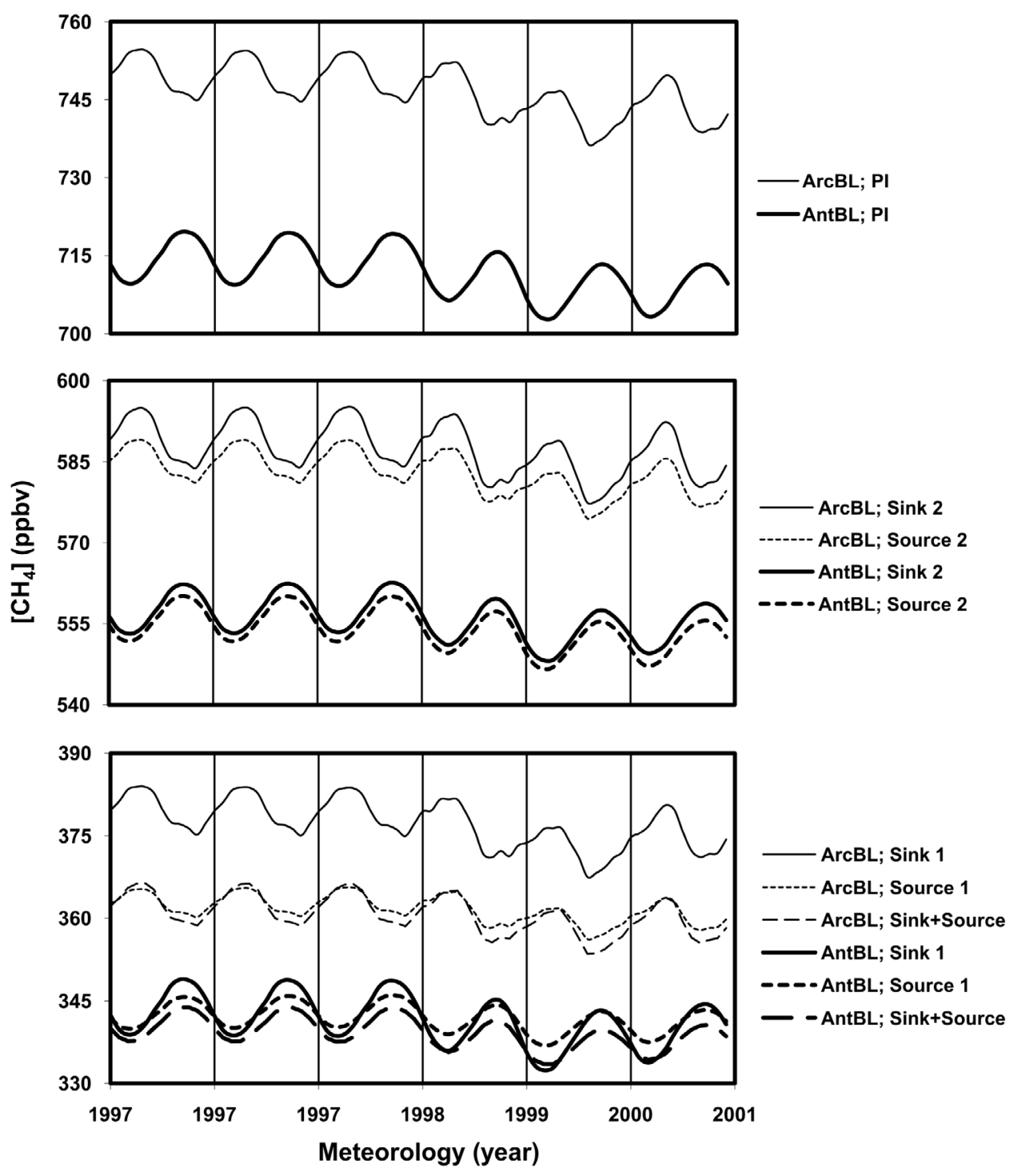

Figure 3. The monthly mean concentration of methane modeled in the Arctic boundary layer (ArcBL) and the Antarctic boundary layer (AntBL), plotted as a function of the meteorology used to drive the model in (top) the PI run, and in the five sensitivity experiments: (bottom) Sink 1, Source 1, and Sink +Source and (middle) Sink 2 and Source 2. In each case, the data shown correspond to the last 3 years of the run to "chemical equilibrium" $(3 \times 1997)$ and the subsequent 3 year run to gather data $(1998-2000)$.

equates to just less than half the change in methane observed between the LGM ( 360 ppbv) and the PI ( 700 ppbv). A similar reduction in AntBL methane is achieved in Source 2 (Figure 3, middle) by reducing the emissions of methane by $17 \%$. Meanwhile, the concentration of methane in the ArcBL is reduced to 585 ppbv in Sink 2 and 581 ppbv in Source 2, giving interhemispheric gradients of $31 \mathrm{ppbv}$ and 29 ppbv, respectively. As before, in Source 2, the gradient in methane scales linearly with the amount of methane emitted because the emissions of methane are scaled uniformly.

\subsection{Chemical Sensitivities in the AntBL}

[21] Table 2 gives the annual mean concentration of each chemical species in the AntBL, calculated in the PI model run, and the percentage change in this, calculated in each sensitivity experiment. Strictly, the annual mean PI concentration $\left([\mathrm{X}]_{\mathrm{PI}}\right)$ is the mean of three annual mean con- centrations corresponding to the three years of meteorology (1998-2000) with which the model is driven. Likewise, each percentage change in concentration (e.g., $\Delta[\mathrm{X}]_{\text {Sink1-PI }}$ ) is the mean of three percentage changes in annual mean concentration (relative to the PI), each subject to a different year's meteorology. The corresponding standard deviations are also given in Table 2. The species in Table 2 are listed in order of the difference between the percentage changes in concentration, or 'sensitivities,' they exhibit in Sink 1 and Source 1 (i.e., $\left|\Delta[\mathrm{X}]_{\text {Sink1-PI }}-\Delta[\mathrm{X}]_{\text {Source1-PI }}\right|$ ).

[22] In the AntBL, OH shows the greatest difference in sensitivity between the first pair of sensitivity experiments, increasing by $112 \%$ in Sink 1 and $19 \%$ in Source 1 (relative to the PI); the global tropospheric burden of $\mathrm{OH}$ increases by $84 \%$ in Sink 1 and $12 \%$ in Source 1 . However, owing to its high reactivity as a radical species, $\mathrm{OH}$ will not be preserved in the ice record; hence the need for this study. We 
Table 2. The Annual Mean Concentration (Volume Mixing Ratio) of Each Chemical Species in the AntBL Calculated in the PI Model Run, and the Percentage Change in This Concentration Calculated in Each Sensitivity Experiment ${ }^{\mathrm{a}}$

\begin{tabular}{|c|c|c|c|c|c|c|}
\hline Species $(\mathrm{X})$ & {$[\mathrm{X}]_{\mathrm{PI}}(\mathrm{vmr})$} & $\Delta[\mathrm{X}]_{\operatorname{Sink} 1-\mathrm{PI}}(\%)$ & $\Delta[\mathrm{X}]_{\text {Sourcel-PI }}(\%)$ & $\Delta[\mathrm{X}]_{\text {Sink2-PI }}(\%)$ & $\Delta[\mathrm{X}]_{\text {Source2-PI }}(\%)$ & $\Delta[\mathrm{X}]_{\text {Sink+Source-PI }}(\%)$ \\
\hline $\mathrm{OH}$ & $5.27(+/-0.61) \mathrm{E}-15$ & $+112+/-2$ & $+19+/-1$ & $+13+/-1$ & $+7+/-0.3$ & $+29+/-2$ \\
\hline (ISON) & $3.20(+/-0.43) \mathrm{E}-13$ & $-74+/-1$ & $-24+/-1$ & $-100+/-0.0$ & $-10+/-0.3$ & $-100+/-0.0$ \\
\hline $\mathrm{HCOOH}$ & $1.78(+/-0.46) \mathrm{E}-13$ & $-59+/-2$ & $-10+/-0.3$ & $-100+/-0.0$ & $-4+/-0.1$ & $-100+/-0.0$ \\
\hline NALD & $2.33(+/-0.26) \mathrm{E}-13$ & $-64+/-1$ & $-17+/-1$ & $-100+/-0.0$ & $-7+/-0.3$ & $-100+/-0.0$ \\
\hline (MACR) & $5.71(+/-1.56) \mathrm{E}-14$ & $-56+/-3$ & $-12+/-0.3$ & $-100+/-0.0$ & $-5+/-0.1$ & $-100+/-0.0$ \\
\hline (ISOOH) & $5.82(+/-1.15)$ E-15 & $-67+/-6$ & $-24+/-2$ & $-100+/-0.0$ & $-10+/-1$ & $-100+/-0.0$ \\
\hline MPAN & $1.28(+/-0.36) \mathrm{E}-13$ & $-60+/-2$ & $-17+/-0.5$ & $-100+/-0.0$ & $-7+/-0.2$ & $-100+/-0.0$ \\
\hline $\mathrm{C}_{5} \mathrm{H}_{8}$ & $1.66(+/-0.93) \mathrm{E}-16$ & $-51+/-11$ & $-9+/-3$ & $-100+/-0.0$ & $-3+/-1$ & $-100+/-0.0$ \\
\hline HONO & $2.26(+/-0.21) \mathrm{E}-15$ & $+60+/-3$ & $+17+/-0.4$ & $-14+/-4$ & $+6+/-0.2$ & $-1+/-5$ \\
\hline $\mathrm{C}_{2} \mathrm{H}_{6}$ & $1.21(+/-0.05) \mathrm{E}-10$ & $-56+/-1$ & $-15+/-1$ & $-86+/-0.1$ & $-6+/-0.2$ & $-88+/-0.1$ \\
\hline $\mathrm{C}_{2} \mathrm{H}_{4}$ & $7.14(+/-0.54) \mathrm{E}-12$ & $-57+/-1$ & $-16+/-0.4$ & $-95+/-0.3$ & $-7+/-0.1$ & $-96+/-0.3$ \\
\hline HACET & $2.75(+/-0.35) \mathrm{E}-12$ & $-50+/-3$ & $-12+/-1$ & $-100+/-0.0$ & $-5+/-1$ & $-100+/-0.0$ \\
\hline $\mathrm{C}_{3} \mathrm{H}_{8}$ & $1.84(+/-0.14) \mathrm{E}-11$ & $-49+/-1$ & $-13+/-1$ & $-52+/-0.3$ & $-5+/-0.2$ & $-57+/-0.5$ \\
\hline $\mathrm{CH}_{3} \mathrm{CHO}$ & $6.25(+/-0.12) \mathrm{E}-13$ & $-45+/-2$ & $-9+/-1$ & $-81+/-0.3$ & $-4+/-0.3$ & $-83+/-0.3$ \\
\hline $\mathrm{CH}_{3} \mathrm{CO}_{3} \mathrm{H}$ & $2.76(+/-0.10)$ E-12 & $-39+/-2$ & $-8+/-0.3$ & $-94+/-0.1$ & $-3+/-0.1$ & $-94+/-0.1$ \\
\hline PPAN & $8.40(+/-0.02) \mathrm{E}-14$ & $-34+/-3$ & $-3+/-1$ & $-76+/-2$ & $-1+/-0.2$ & $-77+/-1$ \\
\hline $\mathrm{CH}_{3} \mathrm{OOH}$ & $7.94(+/-0.73) \mathrm{E}-11$ & $-14+/-1$ & $-44+/-0.3$ & $-14+/-1$ & $-18+/-0.2$ & $-41+/-1$ \\
\hline $\mathrm{CO}$ & $3.35(+/-0.10)$ E-08 & $-56+/-1$ & $-26+/-1$ & $-62+/-1$ & $-11+/-0.3$ & $-72+/-0.2$ \\
\hline $\mathrm{CH}_{3} \mathrm{CH}_{2} \mathrm{CHO}$ & $7.71(+/-0.39)$ E-14 & $-37+/-2$ & $-8+/-1$ & $-55+/-1$ & $-3+/-0.2$ & $-57+/-0.3$ \\
\hline PAN & $1.34(+/-0.07) \mathrm{E}-11$ & $-30+/-1$ & $-1+/-0.1$ & $-98+/-0.1$ & $-0.3+/-0.1$ & $-98+/-0.1$ \\
\hline $\mathrm{HCHO}$ & $1.28(+/-0.11) \mathrm{E}-11$ & $-11+/-0.5$ & $-40+/-0.1$ & $-21+/-1$ & $-16+/-0.0$ & $-45+/-1$ \\
\hline $\mathrm{CH}_{3} \mathrm{COCH}_{3}$ & $1.40(+/-0.05) \mathrm{E}-10$ & $-32+/-2$ & $-7+/-0.5$ & $-93+/-0.1$ & $-3+/-0.2$ & $-93+/-0.1$ \\
\hline $\mathrm{H}_{2} \mathrm{O}_{2}$ & $3.99(+/-0.21) \mathrm{E}-11$ & $+8+/-0.4$ & $-16+/-0.3$ & $-38+/-1$ & $-7+/-0.1$ & $-46+/-1$ \\
\hline $\mathrm{CH}_{3} \mathrm{CH}_{2} \mathrm{OOH}$ & $5.63(+/-0.15)$ E-13 & $-35+/-3$ & $-11+/-0.2$ & $-80+/-0.2$ & $-4+/-0.1$ & $-82+/-0.3$ \\
\hline (MACROOH) & $8.34(+/-2.09) \mathrm{E}-14$ & $-41+/-3$ & $-18+/-1$ & $-100+/-0.0$ & $-7+/-0.4$ & $-100+/-0.0$ \\
\hline $\mathrm{CH}_{3} \mathrm{CO}_{2} \mathrm{H}$ & $2.01(+/-0.11) \mathrm{E}-12$ & $-31+/-2$ & $-9+/-0.2$ & $-93+/-0.5$ & $-3+/-0.1$ & $-93+/-0.4$ \\
\hline $\mathrm{CH}_{3}\left(\mathrm{CH}_{2}\right)_{2} \mathrm{OOH}$ & $2.75(+/-0.07)$ E-13 & $-32+/-2$ & $-9+/-0.3$ & $-43+/-0.4$ & $-4+/-0.1$ & $-46+/-1$ \\
\hline $\mathrm{CH}_{3} \mathrm{CH}_{2} \mathrm{CH}_{2} \mathrm{OOH}$ & $9.64(+/-0.19)$ E-14 & $-27+/-2$ & $-8+/-0.3$ & $-42+/-0.3$ & $-3+/-0.1$ & $-45+/-1$ \\
\hline $\mathrm{N}_{2} \mathrm{O}_{5}$ & $1.55(+/-0.21)$ E-14 & $-24+/-1$ & $-7+/-1$ & $-44+/-2$ & $-3+/-1$ & $-46+/-1$ \\
\hline $\mathrm{O}_{3}$ & $2.43(+/-0.33)$ E-08 & $-19+/-2$ & $-7+/-0.5$ & $-22+/-3$ & $-3+/-0.2$ & $-27+/-4$ \\
\hline $\mathrm{HO}_{2} \mathrm{NO}_{2}$ & $3.84(+/-0.56) \mathrm{E}-13$ & $-24+/-2$ & $-16+/-0.2$ & $-35+/-3$ & $-6+/-0.1$ & $-44+/-3$ \\
\hline $\mathrm{CH}_{3} \mathrm{ONO}_{2}$ & $3.53(+/-0.06) \mathrm{E}-12$ & $-27+/-1$ & $-33+/-0.3$ & $-42+/-0.2$ & $-13+/-0.1$ & $-59+/-0.2$ \\
\hline $\mathrm{HONO}_{2}$ & $5.72(+/-1.54) \mathrm{E}-12$ & $-5+/-2$ & $-0.4+/-0.2$ & $-13+/-5$ & $-0.1+/-0.1$ & $-14+/-5$ \\
\hline $\mathrm{CH}_{3} \mathrm{COCH}_{2} \mathrm{OOH}$ & $6.09(+/-0.24)$ E-13 & $-0.4+/-4$ & $-1+/-0.2$ & $-91+/-0.2$ & $-0.3+/-0.1$ & $-91+/-0.2$ \\
\hline $\mathrm{CH}_{4}$ & $7.09(+/-0.02)$ E-07 & $-52+/-0.1$ & $-52+/-0.0$ & $-22+/-0.1$ & $-22+/-0.0$ & $-52+/-0.1$ \\
\hline MGLY & $5.15(+/-0.27) \mathrm{E}-14$ & $0.0+/-1$ & $0.1+/-1$ & $-97+/-0.4$ & $-0.1+/-0.2$ & $-97+/-0.4$ \\
\hline $\mathrm{H}_{2} \mathrm{O}$ & $1.14(+/-0.00) \mathrm{E}-03$ & $0.0+/-0.0$ & $0.0+/-0.0$ & $0.0+/-0.0$ & $0.0+/-0.0$ & $0+/-0.0$ \\
\hline
\end{tabular}

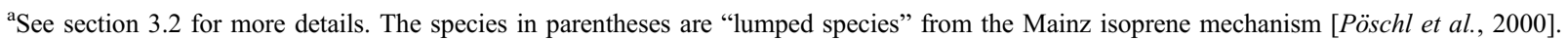

can similarly discount all other radical species (not shown in Table 2), and those species which are rapidly broken down into radicals ( $\mathrm{HONO}$ and $\mathrm{N}_{2} \mathrm{O}_{5}$ ), from our list of potential chemical signals. Note that increasing the concentration of $\mathrm{OH}$ in Sink 1, by increasing the production of $\mathrm{OH}$, reduces the concentration of methane, while reducing the concentration of methane in Source 1 and Source 2, by reducing the amount of methane emitted, increases the concentration of $\mathrm{OH}$, in the AntBL, by $19 \%$ and $7 \%$, respectively; the global tropospheric burden of $\mathrm{OH}$ increases by $12 \%$ and $5 \%$. $\mathrm{OH}$ and methane thus exhibit an interdependence that limits the extent to which we can separately explore the effects of changes in $\mathrm{OH} / \mathrm{methane}$ emissions. This interdependence also constitutes a small positive feedback that reinforces any change we make to $\mathrm{OH}$ or methane [Prather, 1996], evidenced by the slightly greater-than-linear reductions in AntBL methane in Source 1 and Source 2, of 52\% and 22\% respectively, in response to $45 \%$ and $17 \%$ reductions in methane emissions. (Here, the feedback comprises a reduction in methane lifetime due to an increase in $\mathrm{OH}$, as seen in previous theoretical studies [e.g., Isaksen and Hov, 1987].)
[23] Isoprene $\left(\mathrm{C}_{5} \mathrm{H}_{8}\right)$ and a number of its degradation products (ISON, NALD, MACR, ISOOH, MPAN and HACET) show substantially different sensitivities in Sink 1 and Source 1 , decreasing by $50-70 \%$ and $10-20 \%$, respectively. The 'lumped species' (indicated by parentheses in Table 2), used to describe the oxidation of isoprene in the Mainz Isoprene Mechanism [Pöschl et al., 2000], could in principle provide useful chemical signals, so long as all their (major) constituents are preserved in the ice. However, owing to the negligible concentrations these species exhibit in the PI AntBL, these percentage changes equate to changes in concentration that would be very difficult to detect. Note that the concentration of isoprene, and that of each species derived exclusively from its oxidation, decreases by $100 \%$ in Sink 2 and Sink+Source because the emissions from vegetation, which comprise the only source of isoprene in the model, are removed in these experiments.

[24] Ethane $\left(\mathrm{C}_{2} \mathrm{H}_{6}\right)$, ethene $\left(\mathrm{C}_{2} \mathrm{H}_{4}\right)$ and propane $\left(\mathrm{C}_{3} \mathrm{H}_{8}\right)$ show substantially different sensitivities in Sink 1 and Source 1 , decreasing by $50-60 \%$ and $10-15 \%$, respectively. Furthermore, these percentage changes equate to nonnegligible changes in concentration, of between 1 and 10 pptv. However, just as it is difficult to differentiate between changes in 
Table 3. Modeled and Estimated Percentage Changes in the Concentration of $\mathrm{OH}$ in the AntBL, in Each Sensitivity Experiment, Relative to the PI Model Run ${ }^{\mathrm{a}}$

\begin{tabular}{lccccc}
\hline & $\Delta[\mathrm{OH}]_{\text {Sink1-PI }}(\%)$ & $\Delta[\mathrm{OH}]_{\text {Source1-PI }}(\%)$ & $\Delta[\mathrm{OH}]_{\text {Sink2-PI }}(\%)$ & $\Delta[\mathrm{OH}]_{\text {Source2-PI }}(\%)$ & $\Delta[\mathrm{OH}]_{\text {Sink+Source-PI }}(\%)$ \\
\hline Modeled & +112 & +19 & +13 & +7 & +29 \\
Estimated & +102 & +27 & +1 & +9 & +17 \\
\hline
\end{tabular}

${ }^{\text {a }}$ The estimated changes in $\mathrm{OH}$ are calculated based on the modeled changes in the annual-mean AntBL concentrations of HCHO and methane using the formula proposed by Staffelbach et al. [1991]; see section 3.2 for more details.

methane emissions and changes in $\mathrm{OH}$, so it would be difficult to differentiate between changes in the sources and sinks of these hydrocarbons, since oxidation by $\mathrm{OH}$ also comprises their main sink. To infer changes in $\mathrm{OH}$ from changes in their concentrations, we would need to know if and how their emissions had changed between the LGM and the PI.

[25] Carbon monoxide (CO) exhibits a moderate difference in sensitivity in the first pair of experiments, decreasing by $56 \%$ in Sink 1 and $26 \%$ in Source 1 . Furthermore, these percentage changes equate to sizable changes in concentration, on the order of 10 ppbv. However, since its concentration changes in the same sense (decreases) in both experiments, a change in its concentration could not be attributed unambiguously to a particular factor affecting methane, in the absence of additional information. Also, the production of $\mathrm{CO}$ within the snowpack as a result of the photochemical decomposition of other organic species, such as peroxides and formaldehyde, could complicate the interpretation of changes in $\mathrm{CO}$ preserved in the ice record [see, e.g., Haan et al., 2001]. It is possible, however, that some information regarding the cause of the LGM-PI change in methane could be gleaned from measurements of the mass-independent fractionation of oxygen isotopes in $\mathrm{CO}, \Delta^{17} \mathrm{O}_{\mathrm{CO}}=\delta^{17} \mathrm{O}_{\mathrm{CO}}-0.52 \delta^{18} \mathrm{O}_{\mathrm{CO}}$. Measurements indicate that $\mathrm{CO}$ exhibits $\Delta^{17} \mathrm{O}_{\mathrm{CO}}=0$ at the point of emission from a variety of $\mathrm{CO}$ sources including biomass burning [Huff and Thiemens, 1998], but increasingly positive $\Delta^{17} \mathrm{O}_{\mathrm{CO}}$ values downstream that, based on the work of Röckmann et al. [1998b], are attributable to the oxidation of $\mathrm{CO}$ by $\mathrm{OH}$. In section 4 , we will discuss what potential there is to infer any change in oxidizing capacity that took place between the LGM and the PI from measurements of $\Delta^{17} \mathrm{O}_{\mathrm{CO}}$ performed on $\mathrm{CO}$ trapped in polar ice.

[26] Hydrogen peroxide $\left(\mathrm{H}_{2} \mathrm{O}_{2}\right)$ is the only nonradical species whose concentration appears to change in an opposite sense (i.e., either increases or decreases) depending on the cause of the change in methane, increasing in Sink 1 by $8 \%$ and decreasing in Source 1 by $16 \%$. Although small, these percentage changes equate to nonnegligible changes in concentration, on the order of $10 \mathrm{pptv}$. We note, however, that $\mathrm{H}_{2} \mathrm{O}_{2}$ decreases in Sink 2, Source 2 and Sink+Source, by $38 \%, 7 \%$ and $46 \%$, respectively. It will therefore be less useful in differentiating between changes in methane emissions and changes in $\mathrm{OH}$, if the latter are driven by changes in emissions from vegetation; we would be reliant on inferring something from the magnitude of the change in $\mathrm{H}_{2} \mathrm{O}_{2}$ concentration.

[27] Peroxy acetyl nitrate (PAN) shows only a modest difference in sensitivity, decreasing by $30 \%$ in Sink 1 and $1 \%$ in Source 1 . However, the lack of sensitivity that PAN shows to changes in methane emissions (confirmed in Source 2) could make it a useful indicator of changes in $\mathrm{OH}$. We note that PAN shows a particularly strong sensitivity to changes in the emissions from vegetation, decreasing by 98\% in Sink 2 and Sink+Source. This presumably reflects the near-complete removal of NMVOCs (see Table 1) from which $\mathrm{CH}_{3} \mathrm{CO}_{3}$ radicals, which combine with $\mathrm{NO}_{2}$ to form PAN, are derived. We would similarly expect PAN to change in response to changes in $\mathrm{NO}_{\mathrm{x}}$ emissions. Changes in climate could also affect PAN, by altering its lifetime with respect to thermal decomposition. We have not, however, explored these additional sensitivities. In section 4, we will discuss the likelihood that PAN is preserved in the ice record.

[28] Formaldehyde (HCHO) also shows a modest difference in sensitivity, decreasing by $11 \%$ in Sink 1 and $40 \%$ in Source 1 . However, the value previously recognized in HCHO [see Staffelbach et al., 1991] lies in its close relationship with methane and $\mathrm{OH}$. Assuming a steady state between HCHO production by methane oxidation and $\mathrm{HCHO}$ loss by photolysis and reaction with OH, Staffelbach et al. [1991] proposed a formula to relate the concentrations of $\mathrm{HCHO}$, methane and $\mathrm{OH}$ in remote regions (i.e., far from $\mathrm{HCHO}$ sources): equation (1), where $\mathrm{k}_{1}$ and $\mathrm{k}_{2}$ are the rate coefficients for the oxidation by $\mathrm{OH}$ of methane and $\mathrm{HCHO}$, respectively, and $\mathrm{k}_{\mathrm{p}}$ is the $\mathrm{J}$ value for $\mathrm{HCHO}$ photolysis.

$$
\begin{aligned}
{[\mathrm{HCHO}] } & =\frac{k_{1} \cdot[\mathrm{OH}] \cdot\left[\mathrm{CH}_{4}\right]}{k_{p}+k_{2} \cdot[\mathrm{OH}]} \quad \text { that rearranges to } \\
{[\mathrm{OH}] } & =\frac{k_{p} \cdot[\mathrm{HCHO}]}{k_{1} \cdot\left[\mathrm{CH}_{4}\right]-k_{2} \cdot[\mathrm{HCHO}]}
\end{aligned}
$$

Staffelbach et al. [1991] went on to suggest that contemporaneous measurements of $\mathrm{HCHO}$ and methane could be used to estimate past $\mathrm{OH}$ concentrations. To test the proposed relationship between atmospheric $\mathrm{HCHO}$, methane and $\mathrm{OH}$, we have calculated how we would expect AntBL $\mathrm{OH}$ to change in each sensitivity experiment based on the modeled changes in AntBL HCHO and methane. These are compared with the modeled changes in AntBL OH (previously shown in Table 2) in Table 3. For these calculations, we have used the same rate coefficients $\left(\mathrm{k}_{1}\right.$ and $\left.\mathrm{k}_{2}\right)$ as used in the model, subject to the model's annual mean AntBL temperature (246K in 1998, 1999 and 2000).

[29] It would appear that reasonable estimates of changes in AntBL $\mathrm{OH}$ can be obtained from known changes in AntBL HCHO and methane; the discrepancies are likely to be at least partly attributable to the production of $\mathrm{HCHO}$ via NMVOC oxidation, which is not included in equation (1), and the transport of HCHO into, and out of, the AntBL. The change in the concentration of $\mathrm{OH}$ in the AntBL may, 
Table 4. Percentage Changes in the $\left[\mathrm{O}_{3}\right] /[\mathrm{OH}]$ and $\left[\mathrm{O}_{3}\right] /\left[\mathrm{H}_{2} \mathrm{O}_{2}\right]$ Ratios in the AntBL, $\Delta\left[\mathrm{O}_{3}\right] /[\mathrm{OH}]$, and $\Delta\left[\mathrm{O}_{3}\right] /\left[\mathrm{H}_{2} \mathrm{O}_{2}\right]$, Based on the Changes in the Annual Mean Concentrations of $\mathrm{OH}, \mathrm{O}_{3}$ and $\mathrm{H}_{2} \mathrm{O}_{2}$ Calculated in Each Sensitivity Experiment, Relative to the PI Model Run ${ }^{\mathrm{a}}$

\begin{tabular}{lccccc}
\hline & Sink 1 & Source 1 & Sink 2 & Source 2 & Sink+Source \\
\hline$\Delta\left[\mathrm{O}_{3}\right] /[\mathrm{OH}](\%)$ & -62 & -22 & -31 & -9 & -43 \\
$\Delta\left[\mathrm{O}_{3}\right] /\left[\mathrm{H}_{2} \mathrm{O}_{2}\right](\%)$ & -25 & +11 & +26 & +4 & +36 \\
\hline
\end{tabular}

${ }^{\mathrm{a}}$ See section 3.2 for more details.

however, be of limited use in inferring the cause of a change in methane, as $\mathrm{OH}$ in the AntBL will not be representative of $\mathrm{OH}$ at low latitudes (i.e., between $30^{\circ} \mathrm{N}$ and $30^{\circ} \mathrm{S}$ ), where most methane is oxidized [see, e.g., Lawrence et al., 2001; Labrador et al., 2004]. This is most evident from the results of Sink 2, in which the removal of emissions from vegetation (concentrated at low latitudes; see Figure 1) leads to a $13 \%$ increase in the concentration of $\mathrm{OH}$ in the AntBL but a $28 \%$ increase in the global tropospheric burden of $\mathrm{OH}$. Additionally, the relationship proposed by Staffelbach et al. [1991] does not appear to be capable of differentiating between a purely source-driven change in methane, and one which is part source-driven, part-sink driven; using equation (1), we estimate a greater increase in AntBL OH in Source 1 than in Sink+Source, but the model shows the reverse (Table 3). We will, nevertheless, discuss $\mathrm{HCHO}$ further in section 4 .

[30] Most of the remaining species show small differences in sensitivity, and hence little potential to provide useful chemical signals. However, one such species, ozone $\left(\mathrm{O}_{3}\right)$, warrants further attention, as does $\mathrm{H}_{2} \mathrm{O}_{2}$ (already mentioned), in light of the large difference in sensitivity $\mathrm{OH}$ exhibits, and the link identified by Savarino et al. [2000] between the relative importance of different S(IV)-oxidation pathways and the mass-independent fractionation of oxygen isotopes in sulfates, $\Delta^{17} \mathrm{O}_{\text {sulfates }}=\delta^{17} \mathrm{O}_{\text {sulfates }}-$ $0.512 \delta^{18} \mathrm{O}_{\text {sulfates. }}$ According to Savarino et al. [2000], $\Delta^{17} \mathrm{O}_{\text {sulfates }}$ is attributable to the transfer of $\Delta^{17} \mathrm{O}$ anomalies in tropospheric $\mathrm{O}_{3}$ and $\mathrm{H}_{2} \mathrm{O}_{2}, 31 \%$ [Johnston and Thiemens, 1997] and 1.7\%o [Savarino and Thiemens, 1999] respectively, to sulfates as they oxidize sulfur dioxide $\left(\mathrm{SO}_{2}\right)$ in the aqueous phase; $\mathrm{OH}$ exhibits near-zero $\Delta^{17} \mathrm{O}$ anomalies in the troposphere [Lyons, 2001], and no anomaly is transferred as it oxidizes $\mathrm{SO}_{2}$ in the gas phase [Savarino et al., 2000]. All else being equal, therefore, a change in the relative concentrations of $\mathrm{OH}, \mathrm{O}_{3}$ and $\mathrm{H}_{2} \mathrm{O}_{2}$, where the $\mathrm{SO}_{2}$ is oxidized, should lead to a change in $\Delta^{17} \mathrm{O}_{\text {sulfates. }}$. Given the large $\Delta^{17} \mathrm{O}$ anomaly in $\mathrm{O}_{3}, \Delta{ }^{17} \mathrm{O}_{\text {sulfates }}$ will be most sensitive to changes in the $\left[\mathrm{O}_{3}\right] /[\mathrm{OH}]$ and $\left[\mathrm{O}_{3}\right] /\left[\mathrm{H}_{2} \mathrm{O}_{2}\right]$ ratios. Table 4 gives the percentage changes in these ratios in the AntBL, based on the changes in annual mean $\mathrm{OH}, \mathrm{O}_{3}$ and $\mathrm{H}_{2} \mathrm{O}_{2}$ concentrations calculated in each sensitivity experiment.

[31] The $\left[\mathrm{O}_{3}\right] /[\mathrm{OH}]$ ratio decreases in all five sensitivity experiments. All else being equal, this should lead to a reduction in the $\Delta^{17} \mathrm{O}$ in sulfates formed in the AntBL. However, with the exception of Sink 1, in which we artificially increase the strength of the $\mathrm{OH}$ source, the $\left[\mathrm{O}_{3}\right] /$ $\left[\mathrm{H}_{2} \mathrm{O}_{2}\right]$ ratio increases in each experiment, tending to increase the $\Delta^{17} \mathrm{O}$ in the sulfates formed here. As we do not know what proportions of $\mathrm{SO}_{2}$ were oxidized by $\mathrm{OH}, \mathrm{O}_{3}$ and $\mathrm{H}_{2} \mathrm{O}_{2}$ in the PI AntBL, we cannot say what the net effect of these changes would be, and it remains to be seen what difference in sensitivity $\Delta{ }^{17} \mathrm{O}_{\text {sulfates }}$ shows to changes in $\mathrm{OH} / \mathrm{methane}$ emissions. These proportions could be estimated using a general circulation model with interactive aerosol dynamics and appropriate chemistry, such as that employed by Cosme et al. [2002] in the Laboratoire de Meteorologie Dynamique-Zoom Tracers model, as could the influence the $\Delta^{17} \mathrm{O}$ in sulfates formed upwind of the AntBL has on the $\Delta^{17} \mathrm{O}_{\text {sulfates }}$ in this region. However, to accurately model, not only the distributions of $\mathrm{SO}_{2}, \mathrm{OH}, \mathrm{O}_{3}$ and $\mathrm{H}_{2} \mathrm{O}_{2}$, but also that of liquid water (necessary for $\mathrm{SO}_{2}$ oxidation in the aqueous phase), and the transport of air to the AntBL, would pose a formidable challenge. With this in mind, we will discuss in section 4 what potential the $\Delta^{17} \mathrm{O}_{\text {sulfates }}$ preserved in Antarctic ice [see, e.g., Alexander et al., 2002; Savarino et al., 2003] has to constrain the cause of the LGM-PI change in methane.

\subsection{Interannual Variability in Meteorology}

[32] Until now, we have only examined annual mean concentrations, and percentage changes therein, averaged over three model years. However, since the three model years employ different meteorological analyses, we have an opportunity to explore interannual variations in the chemical composition of the AntBL resulting from changes in meteorology, specifically to assess whether or not the chemical sensitivities described in section 3.2 prove robust to these. Table 2 gives the mean sensitivity exhibited by each species in each of the five sensitivity experiments and their standard deviations. The sensitivities exhibited by the majority of species show little variability, their standard deviations being equivalent to around $10 \%$ of their mean values, or less. Those exhibited by $\mathrm{HONO}, \mathrm{HONO}_{2}$ and $\mathrm{N}_{2} \mathrm{O}_{5}$ show greater variability, as do those of $\mathrm{C}_{5} \mathrm{H}_{8}$, PPAN and a number of radical species (not shown in Table 2). However, importantly, none of the sensitivities exhibited by species contributing to potentially useful chemical signals (PAN, $\mathrm{HCHO}, \mathrm{OH}, \mathrm{O}_{3}$ or $\mathrm{H}_{2} \mathrm{O}_{2}$ ) show much variability: they prove robust to interannual changes in meteorology.

\subsection{The Definition of the AntBL}

[33] The model's ability to capture the structure of the AntBL, particularly its shallow depth under stable conditions [Davis et al., 2004; Anderson and Neff, 2008], is limited by the vertical resolution of the model, the lowest level being at least $100 \mathrm{~m}$ deep, and the quality of the meteorological analyses with which it is driven; see section 2.1 for more details on the model. Recall, for the purposes of this study, the AntBL was simply defined to comprise all grid boxes in the lowest level of the model, located south of $70^{\circ} \mathrm{S}$. To assess how sensitive our results are to this somewhat arbitrary definition, we have repeated our analysis using two alternative definitions, comprising: all grid boxes in the second lowest level of the model south of $70^{\circ} \mathrm{S}$; and all grid boxes in the lowest level of the model south of $80^{\circ} \mathrm{S}$. Subject to each definition, we calculate a slightly different (areaweighted) average AntBL concentration for each species in the PI model run and each sensitivity experiment (not shown). Importantly, however, the percentage change in 
concentration that each species shows in each sensitivity experiment, relative to the PI, changes very little-by a few percent, at most. The chemical sensitivities described in section 3.2 thus prove insensitive to the precise definition of the AntBL employed.

\section{Summary and Discussion}

\subsection{Summary}

[34] Using an atmospheric chemistry-transport model, we have explored the effects of source- and sink-driven changes in methane on a wide range of chemical species in the AntBL. Our aim has been to identify any atmospheric chemical signals that, provided they are preserved in the ice record on the necessary time scales, could help us to differentiate between the source- and sink-driven components of the increase in methane between the LGM and the PI [Loulergue et al., 2008]. The majority of species have been discounted on the basis that: they show too similar sensitivities to changes in $\mathrm{OH} /$ methane emissions; they are too reactive to be preserved in the ice on the necessary time scales (e.g., radical species); they exhibit negligible concentrations in the PI AntBL (e.g., isoprene and its oxidation products); and/or additional, unknown information is required to interpret changes in their concentrations, such as if and how their source strengths have changed (e.g., other hydrocarbons). Four signals, however, warrant further discussion regarding their preservation in Antarctic ice and issues surrounding their interpretation: the concentration of PAN; the mass-independent fractionation of oxygen isotopes in sulfates, $\Delta^{17} \mathrm{O}_{\text {sulfates }}$, and $\mathrm{CO}, \Delta \Delta^{17} \mathrm{O}_{\mathrm{CO}}$; and the concentration of $\mathrm{HCHO}$.

\subsection{PAN: Short-Term Preservation in the Antarctic Ice Record}

[35] Based on our calculations, changes in the concentration of PAN in the AntBL could be indicative of changes in $\mathrm{OH}$ and/or changes in NMVOC emissions from vegetationa potential driver of changes in $\mathrm{OH}$. We note, however, that the concentration of PAN would also be affected by changes in $\mathrm{NO}_{\mathrm{x}}$ emissions and temperature, which have not been explored; see section 3.2 for more details.

[36] In theory, PAN could be preserved in the ice record in either the gas phase (in air bubbles trapped within the ice) or in aqueous solution (within the ice itself). As a result of wind-pumping and/or rapid accumulation, gaseous PAN could quickly reach depths in the snowpack to which light does not penetrate. Here, photolysis and oxidation by $\mathrm{OH}$ will cease, however, thermal decomposition and dissolution will continue. Based on the kinetic data of Bridier et al. [1991], we estimate that the lifetime of PAN with respect to thermal decomposition will vary between about a week in summer (assuming a temperature of $265 \mathrm{~K}$ ) and roughly a decade in winter (assuming a temperature of 235K). It is therefore unlikely that PAN will survive in the gas phase for more than, at most, 30-40 years (3-4 e-folding lifetimes). According to Kames and Schurath [1995], that which survives decomposition, but instead undergoes dissolution, will be hydrolyzed on time scales on the order of an hour. We conclude that PAN will not be preserved, either in the gas phase or in aqueous solution, on the time scales necessary to explore changes in $\mathrm{OH} /$ methane emissions between the LGM and the PI.

\section{3. $\Delta^{17} \mathrm{O}_{\text {sulfates: }}$ Limited Potential to Constrain the Cause of the LGM-PI Change in Methane}

[37] Samples from the Vostok ice core (East Antarctica) indicate that $\Delta{ }^{17} \mathrm{O}_{\text {sulfates }}$ was about $2 \%$ lower during the last glacial period ( $\sim 60 \mathrm{ka}$ before present) than in the early Holocene ( 10 ka before present) [Alexander et al., 2002]. The question is, what can we infer from this regarding the cause of the change in methane between the LGM and the PI? Alexander et al. [2002] primarily attribute the change in $\Delta{ }^{17} \mathrm{O}_{\text {sulfates }}$ to a change in the relative concentrations of $\mathrm{OH}$, $\mathrm{O}_{3}$ and $\mathrm{H}_{2} \mathrm{O}_{2}$ in the troposphere, and/or a change in cloudprocessing efficiency (i.e., the availability of liquid water for aqueous-phase $\mathrm{SO}_{2}$ oxidation), but identify a number of other factors that could have also affected $\Delta^{17} \mathrm{O}_{\text {sulfates }}$ : the fraction of sulfates from primary sources, which exhibit $\Delta{ }^{17} \mathrm{O}=0$ and thus dilute nonzero $\Delta^{17} \mathrm{O}_{\text {sulfates; }}$; the $\mathrm{pH}$ of water droplets in the atmosphere, which affects the amount of $\mathrm{SO}_{2}$ oxidized by $\mathrm{O}_{3}$, as opposed to $\mathrm{H}_{2} \mathrm{O}_{2}$, in the aqueous phase [Seinfeld and Pandis, 1998]; and the dynamics of the troposphere, which govern the transport of air to the Vostok site. Even if these additional factors could be discounted, or their effects on $\Delta^{17} \mathrm{O}_{\text {sulfates }}$ accurately quantified, it would still be very difficult to deduce, quantitatively, how the relative concentrations of $\mathrm{OH}, \mathrm{O}_{3}$ and $\mathrm{H}_{2} \mathrm{O}_{2}$ changed during the glacial-interglacial transition, this being convolved with the influence of any change in cloud-processing efficiency that accompanied the change in climate.

[38] The only way we can see of quantitatively exploring how changes in the relative concentrations of these oxidants may have contributed to the change in $\Delta^{17} \mathrm{O}_{\text {sulfates }}$ is to use a general circulation model with interactive aerosol dynamics and appropriate chemistry to simulate $\Delta{ }^{17} \mathrm{O}_{\text {sulfates}}$, subject to a variety of meteorological and trace-gas emissions scenarios. Verma et al. [2007] used such a model to explore the present-day atmospheric sulfur budget, finding $\mathrm{OH}, \mathrm{O}_{3}$ and $\mathrm{H}_{2} \mathrm{O}_{2}$ to be responsible, annually, for $29 \%, 30 \%$ and $41 \%$ of $\mathrm{SO}_{2}$ oxidation globally; see Benkovitz et al. [2006] and Berglen et al. [2004] for similar calculations. Using existing knowledge of the $\Delta^{17} \mathrm{O}$ anomalies in tropospheric $\mathrm{O}_{3}$ and $\mathrm{H}_{2} \mathrm{O}_{2}$ [Johnston and Thiemens, 1997; Savarino and Thiemens, 1999], the transfer of these to sulfates via $\mathrm{SO}_{2}$ oxidation [Savarino et al., 2000], and the dilution of these by the mixing-in of primary sulfates [see, e.g., Alexander et al., 2002], the $\Delta^{17} \mathrm{O}_{\text {sulfates }}$ at the Vostok site could be simulated; such an approach has been taken to quantitatively interpret recent observations of $\Delta^{17} \mathrm{O}_{\text {sulfates }}$ in the Indian Ocean marine boundary layer, and at the Alert station in the Arctic [see Alexander et al., 2005, 2009]. It is unlikely, however, that only one meteorological/trace-gas emission scenario would be found that could account for the reduction in $\Delta^{17} \mathrm{O}_{\text {sulfates }}$ during the glacial period (to within the uncertainty of the measurements); recall, we found that the $\left[\mathrm{O}_{3}\right] /[\mathrm{OH}]$ and $\left[\mathrm{O}_{3}\right] /\left[\mathrm{H}_{2} \mathrm{O}_{2}\right]$ ratios, at least in the AntBL, responded in the same sense to an increase in $\mathrm{OH}$ (driven by a reduction in NMVOC emissions from vegetation) and/or a reduction in methane emissions; see section 3.2. Furthermore, given the lifetime of sulfate aerosol, $\Delta^{17} \mathrm{O}_{\text {sulfates }}$ in Antarctic ice could reflect changes in oxidative conditions 


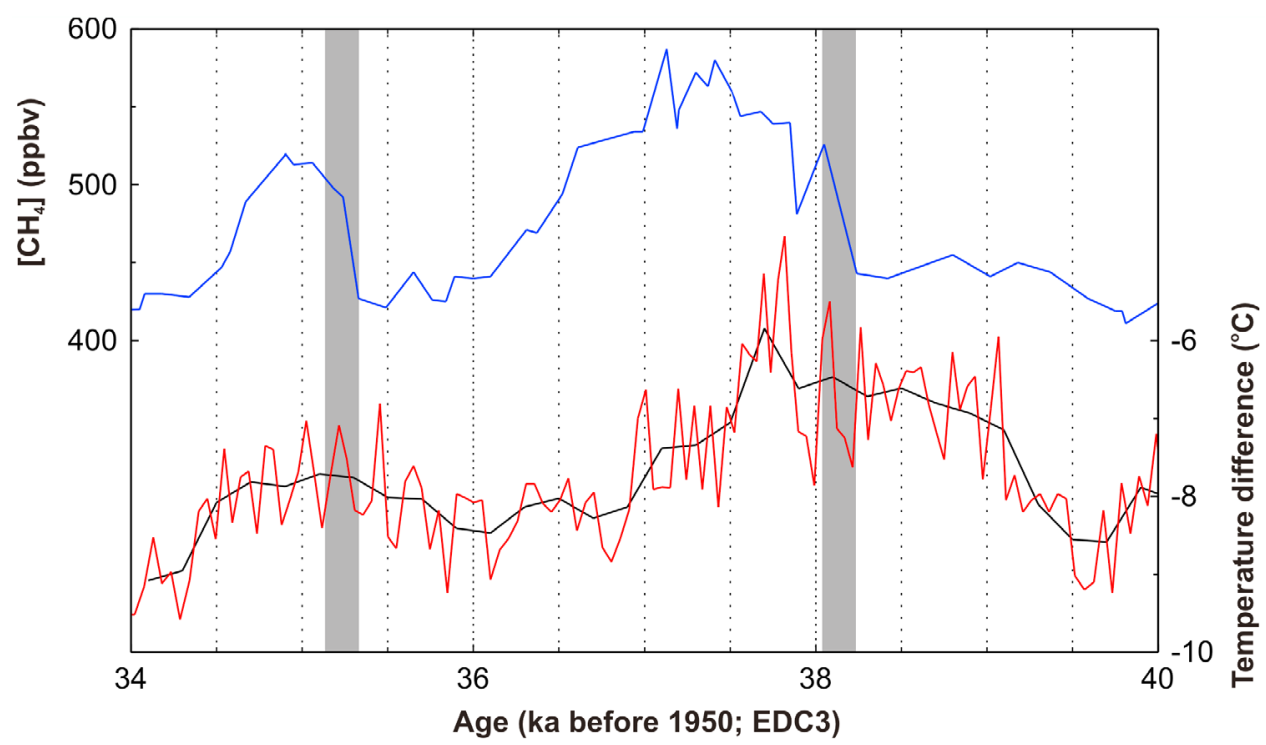

Figure 4. Measurements of methane concentration (blue line) and temperature (relative to the late Holocene; red line) from Dome C, Antarctica, spanning Dansgaard-Oeschger events 7 and 8 (roughly 35 and 38 ka before 1950); the data are taken from Loulergue et al. [2008] and Jouzel et al. [2007], respectively. The regions shaded gray indicate periods of 200 years at the beginning of these events, in which the concentration of methane changes by between 70 and $80 \mathrm{ppbv}$, or $15-20 \%$, while the temperature, smoothed on a 200 year time scale (black line), hardly changes; see section 4.5 for more details.

over much of the Southern Ocean, but is unlikely to tell us much about changes in $\mathrm{OH}$ at low latitudes, where most methane is oxidized [see, e.g., Lawrence et al., 2001; Labrador et al., 2004]. Coupled to the large uncertainties in meteorology and chemistry, to which simulations of $\Delta \Delta^{17} \mathrm{O}_{\text {sulfates }}$ would be subject, we conclude that $\Delta{ }^{17} \mathrm{O}_{\text {sulfates }}$ has limited potential to constrain the cause of the LGM-PI change in methane.

\section{4. $\Delta^{17} \mathrm{O}_{\mathrm{CO}}$ : Some Potential to Constrain the Cause of the LGM-PI Change in Methane}

[39] Records of atmospheric CO concentration spanning the last 200 and 2000 years have been obtained from Antarctic and Greenland ice cores [Haan et al., 1996; Haan and Raynaud, 1998]. However, it remains to be seen whether an ice core record of $\Delta^{17} \mathrm{O}_{\mathrm{CO}}$ spanning the last $21 \mathrm{ka}$ can be obtained, and the extent to which an accurate record of atmospheric $\Delta^{17} \mathrm{O}_{\mathrm{CO}}$ could be derived from it; any $\mathrm{CO}$ produced in the snowpack [see Haan et al., 2001], assuming this exhibits $\Delta^{17} \mathrm{O}_{\mathrm{CO}}=0$, would dilute the nonzero atmospheric $\Delta^{17} \mathrm{O}_{\mathrm{CO}}$, and any $\mathrm{OH}$ present in the uppermost layer of the snowpack, into which light can penetrate, could continue to alter $\Delta^{17} \mathrm{O}_{\mathrm{CO}}$. But if we suppose a suitable record of atmospheric $\Delta^{17} \mathrm{O}_{\mathrm{CO}}$ could be obtained, based on the work of Huff and Thiemens [1998] and Röckmann et al. [1998b], it would contain information on the degree to which $\mathrm{CO}$ transported to the ice core site had been exposed to $\mathrm{OH}$-an average over all air parcels transported to that site, smoothed on the time scale it took sufficient snow to accumulate, and compress under its own weight, to the point of the closure.

[40] $\Delta^{17} \mathrm{O}_{\mathrm{CO}}$ has some advantages over $\Delta^{17} \mathrm{O}_{\text {sulphates, }}$, so far as inferring a change in oxidizing capacity is concerned: $\mathrm{CO}$ has a much longer lifetime, on the order of weeks to months as opposed to days, and consequently $\Delta^{17} \mathrm{O}_{\mathrm{CO}}$ should contain more information on $\mathrm{OH}$ at low latitudes; and the modeling of $\Delta^{17} \mathrm{O}_{\mathrm{CO}}$ would not require the modeling of the distribution of liquid water to the same degree of accuracy, since the relevant gas-phase reaction (between $\mathrm{CO}$ and $\mathrm{OH}$ ) is not in direct competition with reactions in the aqueous phase. However, it would not be trivial to infer quantitative changes in $\mathrm{OH}$ from changes in $\Delta^{17} \mathrm{O}_{\mathrm{CO}}$, since the integrated exposure of $\mathrm{CO}$ to $\mathrm{OH}$ is a function, not only of the $\mathrm{OH}$ concentrations present between the source of $\mathrm{CO}$ and the site of the ice core, but also the time for which the $\mathrm{CO}$ is exposed to those concentrations of $\mathrm{OH}$, which is dependent on two factors that could change with climate: the location of the CO source; and the atmospheric circulation governing its transport to the ice core site. The changes in $\Delta^{17} \mathrm{O}_{\mathrm{CO}}$ due to changes in $\mathrm{OH}$ would also have to be separated from those due to changes in the amount of $\mathrm{CO}$ produced via the ozonolysis of unsaturated hydrocarbons, such as isoprene and terpenes [Röckmann et al., 1998a]. We therefore conclude that $\Delta^{17} \mathrm{O}_{\mathrm{CO}}$ may have some potential to constrain the cause of the LGM-PI change in methane, but further work is needed before this can be fully assessed.

\subsection{HCHO: Synchronization of Gas- and Aqueous- Phase Antarctic Ice Records}

[41] Ever since it was proposed by Staffelbach et al. [1991], there has been considerable interest in the use of contemporaneous measurements of $\mathrm{HCHO}$ and methane to estimate past $\mathrm{OH}$ concentrations. Our calculations confirm that, at least in our model domain, reasonably good estimates of changes in AntBL OH can be obtained from known changes in AntBL HCHO and methane using their formula: equation (1) in section 3.2. However, we face two problems with regards to using the $\mathrm{HCHO}$ preserved in Antarctic ice 
to determine the cause of the LGM-PI change in methane. First, the concentration of $\mathrm{HCHO}$ preserved in the ice differs from that which was present in the boundary layer, at the time of deposition, as a result of physical processes operating during and postdeposition [Hutterli et al., 1999, 2002]; if we were not focused on the pristine environment of the PI AntBL, we would also have to consider $\mathrm{HCHO}$ production within the snowpack [Sumner and Shepson, 1999; Dominé and Shepson, 2002]. The physical processes operate to greater or lesser extents depending on a number of climatic variables: the temperature, the degree to which the snowpack is ventilated, and the rate and seasonality of accumulation. According to Hutterli et al. [2003], the preservation of $\mathrm{HCHO}$ is not especially sensitive to changes in ventilation, while past temperatures and accumulation rates can be determined from measurements of $\delta^{18} \mathrm{O}$ and annual layer thickness respectively. However, uncertainty surrounding past changes in the seasonality of accumulation make it a formidable challenge to obtain a reliable record of AntBL $\mathrm{HCHO}$ during periods of climate change, such as that between the LGM and the PI. The second problem is that even if we were able to obtain a reliable record of AntBL $\mathrm{HCHO}$, and thereby infer a change in AntBL OH, we still would not know if, and how, the oxidizing capacity had changed at lower latitudes, where most methane is oxidized [see, e.g., Lawrence et al., 2001; Labrador et al., 2004].

[42] In one respect, however, the Antarctic ice record of HCHO does have potential: to synchronize the gas- and aqueous-phase Antarctic ice records. The gas-phase record includes information regarding past atmospheric $\mathrm{CO}_{2}$ concentrations, while the aqueous-phase record holds information on past changes in temperature $\left(\delta^{18} \mathrm{O}\right)$. Precisely determining the phasing between the changes in $\mathrm{CO}_{2}$ and temperature requires a synchronization of contemporaneous events in the two records. This has been achieved in Greenland by aligning changes in $\delta^{18} \mathrm{O}$ (aqueous phase) and $\delta^{15} \mathrm{~N}$ (gas phase) accompanying rapid changes in temperature [see, e.g., Severinghaus et al., 1998]. However, the changes in temperature in the Antarctic are not sufficiently rapid to achieve adequate synchronicity, and an alternative signal has yet to be identified. If an aqueous-phase signal could be found that responds to rapid changes in methane preserved in the gas phase, synchronization could be achieved.

[43] Figure 4 illustrates measurements of methane concentration (blue line) and temperature (relative to the late Holocene; red line) from Dome C, Antarctica, spanning Dansgaard-Oeschger events 7 and 8 (roughly 35 and 38 ka before 1950); the data are taken from Loulergue et al. [2008] and Jouzel et al. [2007] respectively. The regions shaded gray indicate periods of 200 years at the beginning of these events, in which the concentration of methane increases rapidly by $70-80 \mathrm{ppbv}$, or $15-20 \%$, while the temperature, smoothed on a 200 year time scale (black line), hardly changes. This is in stark contrast to the situation in Greenland, where the rapid changes in methane concentration took place during periods of rapid climate change, which would have influenced the preservation of $\mathrm{HCHO}$ in Greenland ice [Fuhrer et al. 1993]. In Antarctica, the slowly varying climate should only lead to modest and smooth variations in $\mathrm{HCHO}$ concentration, on top of which each rapid $15-20 \%$ rise in methane concentration (recorded in the gas phase) should superimpose a rapid $15-20 \%$ rise in $\mathrm{HCHO}$ concentration (recorded in the aqueous phase); see equation (1) in section 3.2. For each such rise in $\mathrm{HCHO}$ concentration that could be detected and aligned with the corresponding rise in methane concentration, the gas- and aqueous-phase Antarctic ice records could be synchronized. The relative phasing of glacial-interglacial changes in $\mathrm{CO}_{2}$ and temperature in the Southern Hemisphere could thus be determined. To determine whether $\mathrm{CO}_{2}$ 'led' temperature in this region, or temperature 'led' $\mathrm{CO}_{2}$, would represent a key step forward in understanding past climate change.

\subsection{Concluding Remarks}

[44] Despite the potentially positive use of HCHO discussed above, our bottom-up model study has not readily identified a chemical signal, likely to be measurable in Antarctic ice cores, that provides a simple and robust constraint on the sizes of the source- and sink-driven changes in atmospheric methane between the LGM and the PI. We have only explored a domain in which $\mathrm{NO}_{\mathrm{x}}$ emissions and climate remain constant. However, given the uncertainties associated with the changes in these factors, we would anticipate their inclusion to make it harder still to identify a robust signal. For the time being at least, we suggest a full understanding of the increase in atmospheric methane between the LGM and the PI will have to rely on a combination of: direct observational constraints on the methane budget in ice cores, such as $\delta^{13} \mathrm{CH}_{4}$ and $\delta \mathrm{D}\left(\mathrm{CH}_{4}\right)$ [see, e.g., Fischer et al., 2008]; data syntheses leading to improved quantification of changes in methane (and NMVOC) sources [see, e.g., Power et al., 2008]; and comprehensive Earth system models with which we can integrate these.

[45] Acknowledgments. This study is part of the British Antarctic Survey Polar Science for Planet Earth Programme and a contribution to the Dynamics of the Earth System and the Ice core Record project, the latter being jointly funded by the Natural Environment Research Council's program, Quantifying and Understanding the Earth System, and the French Institut National des Sciences de l'Univers; we gratefully acknowledge their support. The authors also wish to thank: Paul Valdes of the School of Geographical Sciences, University of Bristol, for the PI emissions; Nicola Warwick of the Centre for Atmospheric Science, University of Cambridge, for her help in implementing these emissions in the Cambridge p-TOMCAT model; and three anonymous reviewers for their insightful comments.

\section{References}

Adams, J. M., J. V. H. Constable, A. B. Guenther, and P. Zimmerman (2001), An estimate of natural volatile organic compound emissions from vegetation since the Last Glacial Maximum, Chemos. Global Change Sci., 3, 73-91, doi:10.1016/S1465-9972(00)00023-4.

Alexander, B., J. Savarino, N. I. Barkov, R. J. Delmas, and M. H. Thiemens (2002), Climate driven changes in the oxidation pathways of atmospheric sulphur, Geophys. Res. Lett., 29(14), 1685, doi:10.1029/2002GL014879.

Alexander, B., J. Savarino, C. C. W. Lee, R. J. Park, D. J. Jacob, Q. Li, R. M. Yantosca, and M. H. Thiemens (2005), Sulfate formation in sea-salt aerosols: Constraints from oxygen isotopes, J. Geophys. Res., 110, D10307, doi:10.1029/2004JD005659.

Alexander, B., R. J. Park, D. J. Jacob, and S. L. Gong (2009), Transition metal-catalyzed oxidation of atmospheric sulfur: Global implications for the sulfur budget, J. Geophys. Res., 114, D02309, doi:10.1029/ 2008JD010486.

Anderson, P. S., and W. D. Neff (2008), Boundary layer physics over snow and ice, Atmos. Chem. Phys., 8, 3563-3582, doi:10.5194/acp-8-35632008.

Arneth, A., et al. (2007), Process-based estimates of terrestrial ecosystem isoprene emissions: Incorporating the effects of a direct $\mathrm{CO} 2$-isoprene interaction, Atmos. Chem. Phys., 7, 31-53, doi:10.5194/acp-7-31-2007. 
Benkovitz, C. M., S. E. Schwartz, M. P. Jensen, and M. A. Miller (2006), Attribution of modeled atmospheric sulfate and $\mathrm{SO}_{2}$ in the Northern Hemisphere for June-July 1997, Atmos. Chem. Phys., 6, 4723-4738, doi:10.5194/acp-6-4723-2006.

Berglen, T. F., T. K. Berntsen, I. S. A. Isaksen, and J. K. Sundet (2004), A global model of the coupled sulfur/oxidant chemistry in the troposphere: The sulfur cycle, J. Geophys. Res., 109, D19310, doi:10.1029/ 2003JD003948.

Berntsen, T. K., and I. S. A. Isaksen (1997), A global three-dimensiona chemical transport model for the troposphere: 1. Model description and $\mathrm{CO}$ and ozone results, J. Geophys. Res., 102, 21,239-21,280, doi:10.1029/97JD01140.

Braconnot, P., et al. (2007), Results of PMIP2 coupled simulations of the Mid-Holocene and Last Glacial Maximum-Part 1: Experiments and large-scale features, Clim. Past, 3, 261-277, doi:10.5194/cp-3-261-2007.

Bridier, I., F. Caralp, H. Loirat, R. Lesclaux, B. Veyret, K. H. Becker, A. Reimer, and F. Zabel (1991), Kinetic and theoretical studies of the reactions $\mathrm{CH}_{3} \mathrm{C}(\mathrm{O}) \mathrm{O}_{2}+\mathrm{NO}_{2}+\mathrm{M} \leftrightarrow \mathrm{CH}_{3} \mathrm{C}(\mathrm{O}) \mathrm{O}_{2} \mathrm{NO}_{2}+\mathrm{M}$ between 248 and $393 \mathrm{~K}$ and between 30 and 760 Torr, J. Phys. Chem., 95, 3594-3600, doi:10.1021/j100162a031.

Carver, G. D., and P. A. Stott (2000), IMPACT: An implicit time integration scheme for chemical species and families, Ann. Geophys., 18, 18,337-18,346.

Carver, G. D., P. D. Brown, and O. Wild (1997), The ASAD atmospheric chemistry integration package and chemical reaction database, Comput. Phys. Commun., 105, 197-215, doi:10.1016/S0010-4655(97)00056-8.

Chandra, S., J. R. Ziemke, W. Min, and W. G. Read (1998), Effects of 1997-1998 El Niño on tropospheric ozone and water vapour, Geophys. Res. Lett., 25, 3867-3870, doi:10.1029/98GL02695.

Chappellaz, J., T. Blunier, D. Raynaud, J. M. Barnola, J. Schwander, and B. Stauffert (1993a), Synchronous changes in atmospheric $\mathrm{CH}_{4}$ and Greenland climate between 40 and 8 kyr BP, Nature, 366, 443-445, doi:10.1038/366443a0.

Chappellaz, J. A., I. Y. Fung, and A. M. Thompson (1993b), The atmospheric $\mathrm{CH}_{4}$ increase since the Last Glacial Maximum (1). Source estimates, Tellus, Ser. B, 45, 228-241.

Chappellaz, J., T. Blunier, S. Kints, A. Dällenbach, J.-M. Barnola, J. Schwander, D. Raynaud, and B. Stauffer (1997), Changes in the atmospheric $\mathrm{CH}_{4}$ gradient between Greenland and Antarctica during the Holocene, J. Geophys. Res., 102, 15,987-15,997, doi:10.1029/97JD01017.

Chipperfield, M. P. (1996), The TOMCAT offline transport model, Part II. Dynamics and advection, UGAMP Internal Rep. 44b, Dep. of Meteorol., Univ. of Reading, Reading, U. K.

Cook, P., et al. (2007), Forest fire plumes over the North Atlantic: p-TOMCAT model simulations with aircraft and satellite measurements from the ITOP/ICARTT Campaign, J. Geophys. Res., 112, D10S43, doi:10.1029/ 2006JD007563.

Cosme, E., C. Genthon, P. Martinerie, O. Boucher, and M. Pham (2002), The sulfur cycle at high-southern latitudes in the LMD-ZT General Circulation Model, J. Geophys. Res., 107(D23), 4690, doi:10.1029/ 2002JD002149.

Dällenbach, A., T. Blunier, J. Flückiger, B. Stauffer, J. Chappellaz, and D. Raynaud (2000), Changes in the atmospheric $\mathrm{CH}_{4}$ gradient between Greenland and Antarctica during the last glacial and the transition to the Holocene, Geophys. Res. Lett., 27, 1005-1008, doi:10.1029/ 1999GL010873.

Davis, D., G. Chen, M. Buhr, J. Crawford, D. Lenschow, B. Lefer, R. Shetter, F. Eisele, L. Mauldin, and A. Hogan (2004), South Pole $\mathrm{NO}_{\mathrm{x}}$ chemistry: An assessment of factors controlling variability and absolute levels, Atmos. Environ., 38, 5375-5388, doi:10.1016/j.atmosenv.2004.04.039.

Dominé, F., and P. B. Shepson (2002), Air-snow interactions and atmospheric chemistry, Science, 297, 1506-1510, doi:10.1126/science. 1074610 .

Fischer, H., et al. (2008), Changing boreal methane sources and constant biomass burning during the last termination, Nature, 452, 864-867, doi:10.1038/nature06825.

Fuhrer, K., A. Neftel, M. Anklin, and V. Maggi (1993), Continuous measurements of hydrogen peroxide, formaldehyde, calcium and ammonium concentrations along the new GRIP core from Summit, central Greenland, Atmos. Environ., Part A, 27(12), 1873-1880.

Giannakopoulos, C., M. P. Chipperfield, K. S. Law, and J. A. Pyle (1999), Validation and intercomparison of wet and dry deposition schemes using ${ }^{210} \mathrm{~Pb}$ in a global three-dimensional off-line chemical transport model, J. Geophys. Res., 104, 23761-23784, doi:10.1029/1999JD900392.

Gillett, R. W., T. D. van Ommen, A. V. Jackson, and G. P. Ayers (2000), Formaldehyde and peroxide concentrations in Law Dome (Antarctica) firn and ice cores, J. Glaciol., 46(152), 15-19, doi:10.3189/ 172756500781833502 .
Grannas, A. M., et al. (2007), An overview of snow photochemistry: Evidence, mechanisms and impacts, Atmos. Chem. Phys., 7, 4329-4373, doi:10.5194/acp-7-4329-2007.

Haan, D., and D. Raynaud (1998), Ice core record of CO variations during the last two millennia: Atmospheric implications and chemical interactions within the Greenland ice, Tellus, Ser. B, 50, 253-262.

Haan, D., P. Martinerie, and D. Raynaud (1996), Ice core data of atmospheric carbon monoxide over Antarctica and Greenland during the last 200 years, Geophys. Res. Lett., 23, 2235-2238, doi:10.1029/96GL02137.

Haan, D., Y. Zuo, V. Gros, and C. A. M. Brenninkmeijer (2001), Photochemical production of carbon monoxide in snow, J. Atmos. Chem., 40, 217-230, doi:10.1023/A:1012216112683.

Holtslag, A. A. M., and B. A. Boville (1993), Local versus nonlocal boundary-layer diffusion in a global climate model, J. Clim., 6, 1825-1842, doi:10.1175/1520-0442(1993)006<1825:LVNBLD>2.0.CO;2.

Huff, A. K., and M. H. Thiemens $(1998),{ }^{17} \mathrm{O} /{ }^{16} \mathrm{O}$ and ${ }^{18} \mathrm{O} /{ }^{16} \mathrm{O}$ isotope measurements of atmospheric carbon monoxide and its sources, Geophys. Res. Lett., 25, 3509-3512, doi:10.1029/98GL02603.

Hutterli, M. A., R. Röthlisberger, and R. C. Bales (1999), Atmosphere-tosnow-to-firn transfer studies of HCHO at Summit, Greenland, Geophys. Res. Lett., 26, 1691-1694, doi:10.1029/1999GL900327.

Hutterli, M. A., R. C. Bales, J. R. McConnell, and R. W. Stewart (2002), $\mathrm{HCHO}$ in Antarctic snow: Preservation in ice cores and air-snow exchange, Geophys. Res. Lett., 29(8), 1235, doi:10.1029/2001GL014256.

Hutterli, M. A., J. R. McConnell, R. C. Bales, and R. W. Stewart (2003), Sensitivity of hydrogen peroxide $\left(\mathrm{H}_{2} \mathrm{O}_{2}\right)$ and formaldehyde $(\mathrm{HCHO})$ preservation in snow to changing environmental conditions: Implications for ice core records, J. Geophys. Res., 108(D1), 4023, doi:10.1029/ 2002JD002528.

Isaksen, I. S. A., and O. Hov (1987), Calculation of trends in tropospheric $\mathrm{O}_{3}, \mathrm{OH}, \mathrm{CH}_{4}, \& \mathrm{NO}_{\mathrm{x}}$, Tellus, Ser. B, 39, 271-285, doi:10.1111/j.16000889.1987.tb00099.x.

Johnston, J. C., and M. H. Thiemens (1997), The isotopic composition of tropospheric ozone in three environments, J. Geophys. Res., 102, 25,395-25,404, doi:10.1029/97JD02075.

Jouzel, J., et al. (2007), Orbital and millennial Antarctic climate variability over the past 800,000 years, Science, 317, 793-796, doi:10.1126/ science. 1141038 .

Kames, J., and U. Schurath (1995), Henry's Law and hydrolysis-rate constants for peroxyacyl nitrates (PANs) using a homogeneous gas-phase source, J. Atmos. Chem., 21, 151-164, doi:10.1007/BF00696578.

Kaplan, J. O. (2002), Wetlands at the Last Glacial Maximum: Distribution and methane emissions, Geophys. Res. Lett., 29(6), 1079, doi:10.1029/ 2001GL013366

Kaplan, J. O., G. Folberth, and D. A. Hauglustaine (2006), Role of methane and biogenic volatile organic compound sources in late glacial and Holocene fluctuations of atmospheric methane concentrations, Global Biogeochem. Cycles, 20, GB2016, doi:10.1029/2005GB002590.

Köhler, M. O., G. Rädel, O. Dessens, K. P. Shine, H. L. Rogers, O. Wild, and J. A. Pyle (2008), Impact of perturbations to nitrogen oxide emissions from global aviation, J. Geophys. Res., 113, D11305, doi:10.1029/2007JD009140.

Labrador, L. J., R. von Kuhlmann, and M. G. Lawrence (2004), Strong sensitivity of the global mean $\mathrm{OH}$ concentration and the tropospheric oxidizing efficiency to the source of $\mathrm{NO}_{\mathrm{x}}$ from lightning, Geophys. Res. Lett., 31, L06102, doi:10.1029/2003GL019229.

Lathière, J., D. A. Hauglustaine, and N. De Noblet-Ducoudré (2005), Past and future changes in biogenic volatile organic compound emissions simulated with a global dynamic vegetation model, Geophys. Res. Lett., 32, L20818, doi:10.1029/2005GL024164.

Law, K. S., and J. A. Pyle (1993), Modeling trace gas budgets in the troposphere: 1. Ozone and odd nitrogen, J. Geophys. Res., 98, 18,377-18,400, doi:10.1029/93JD01479.

Lawrence, M. G., P. Jöckel, and R. von Kuhlmann (2001), What does the global mean $\mathrm{OH}$ concentration tell us?, Atmos. Chem. Phys., 1, 37-49, doi:10.5194/acp-1-37-2001.

Lelieveld, J., et al. (2008), Atmospheric oxidation capacity sustained by a tropical forest, Nature, 452, 737-740, doi:10.1038/nature06870.

Levine, J. G., P. Braesicke, N. R. P. Harris, N. H. Savage, and J. A. Pyle (2007), Pathways and timescales for troposphere-to-stratosphere transport via the tropical tropopause layer and their relevance for very short lived substances, J. Geophys. Res., 112, D04308, doi:10.1029/ 2005JD006940.

Loulergue, L., A. Schilt, R. Spahni, V. Masson-Delmotte, T. Blunier, B. Lemieux, J.-M. Barnola, D. Raynaud, T. F. Stocker, and J. Chappellaz (2008), Orbital and millennial-scale features of atmospheric $\mathrm{CH}_{4}$ over the past 800,000 years, Letters to Nature, Nature, 453, 383-386, doi:10.1038/ nature 06950 . 
Lyons, J. R. (2001), Mass-independent fractionation of oxygen-containing radicals in the atmosphere, Geophys. Res. Lett., 28, 3231-3234, doi:10.1029/2000GL012791.

MARGO Project Members (2009), Constraints on the magnitude and patterns of ocean cooling at the last glacial maximum, Nat. Geosci., 2, 127-132, doi:10.1038/ngeo411.

Martinerie, P., G. P. Brasseur, and C. Granier (1995), The chemical composition of ancient atmospheres: A model study constrained by ice core data, J. Geophys. Res., 100, 14,291-14,304, doi:10.1029/95JD00826.

Monnin, E., A. Indermuhle, A. Dallenbach, J. Fluckiger, B. Stauffer, T. F. Stocker, D. Raynaud, and J. M. Barnola (2001), Atmospheric $\mathrm{CO}_{2}$ concentrations over the last glacial termination, Science, 291, 112-114, doi:10.1126/science.291.5501.112.

Otto-Bliesner, B. L., et al. (2009), A comparison of PMIP2 model simulations and the MARGO proxy reconstruction for tropical sea surface temperatures at Last Glacial Maximum, Clim. Dyn., 32, 799-815, doi:10.1007/s00382-008-0509-0.

Platt, U., W. Allan, and D. Lowe (2004), Hemispheric average Cl atom concentration from ${ }^{13} \mathrm{C} /{ }^{12} \mathrm{C}$ ratios in atmospheric methane, Atmos. Chem. Phys., 4, 2393-2399, doi:10.5194/acp-4-2393-2004.

Pöschl, U., R. von Kuhlmann, N. Poisson, and P. J. Crutzen (2000), Development and intercomparison of condensed isoprene oxidation mechanisms for global atmospheric modeling, J. Atmos. Chem., 37, 29-52, doi:10.1023/A:1006391009798.

Power, M. J., et al. (2008), Changes in fire regimes since the Last Glacial Maximum: An assessment based on a global synthesis and analysis of charcoal data, Clim. Dyn., 30, doi:10.1007/s00382-007-0334-x.

Prather, M. J. (1986), Numerical advection by conservation of secondorder moments, J. Geophys. Res., 91, 6671-6681, doi:10.1029/ JD091iD06p06671.

Prather, M. J. (1996), Time scales in atmospheric chemistry: Theory, GWPs for $\mathrm{CH}_{4}$ and $\mathrm{CO}$, and runaway growth, Geophys. Res. Lett., 23, 2597-2600, doi:10.1029/96GL02371.

Röckmann, T., C. A. M. Brenninkmeijer, P. Neeb, and P. J. Crutzen (1998a), Ozonolysis of nonmethane hydrocarbons as a source of the observed mass independent oxygen isotope enrichment in tropospheric CO, J. Geophys. Res., 103, 1463-1470, doi:10.1029/97JD02929.

Röckmann, T., C. A. M. Brenninkmeijer, G. Saueressig, P. Bergamaschi, J. N. Crowley, H. Fischer, and P. J. Crutzen (1998b), Mass-independent oxygen isotope fractionation in atmospheric $\mathrm{CO}$ as a result of the reaction $\mathrm{CO}+\mathrm{OH}$, Science, 281, 544-546, doi:10.1126/science.281.5376.544.

Savarino, J., and M. H. Thiemens (1999), Analytical procedure to determine both $\delta^{18} \mathrm{O}$ and $\delta^{17} \mathrm{O}$ of $\mathrm{H}_{2} \mathrm{O}_{2}$ in natural water and first measurements, Atmos. Environ., 33, 3683-3690, doi:10.1016/S1352-2310(99) 00122-3.

Savarino, J., C. C. W. Lee, and M. H. Thiemens (2000), Laboratory oxygen isotopic study of sulfur (IV) oxidation: Origin of the mass-independent oxygen isotopic anomaly in atmospheric sulfates and sulfate mineral deposits on Earth, J. Geophys. Res., 105, 29,079-29,088, doi:10.1029/ 2000JD900456.

Savarino, J., S. Bekki, J. Cole-Dai, and M. H. Thiemens (2003), Evidence from sulfate mass independent oxygen isotopic compositions of dramatic changes in atmospheric oxidation following massive volcanic eruptions, J. Geophys. Res., 108(D21), 4671, doi:10.1029/2003JD003737.

Seinfeld, J. H., and S. N. Pandis (1998), Chemistry of the atmospheric aqueous phase, in Atmospheric Chemistry and Physics: From Air Pollution to Climate Change, pp. 337-407, Wiley-Intersci., Hoboken, N. J.

Severinghaus, J. P., T. Sowers, E. J. Brook, R. B. Alley, and M. L. Bender (1998), Timing of abrupt climate change at the end of the Younger Dryas interval from thermally fractionated gases in polar ice, Nature, 391, 141-146, doi:10.1038/34346.

Staffelbach, T., A. Neftel, B. Stauffer, and D. Jacob (1991), A record of the atmospheric methane sink from formaldehyde in polar ice cores, Nature, 349, 603-605, doi:10.1038/349603a0.
Stockwell, D. Z., C. Giannakopoulos, P.-H. Plantevin, G. D. Carver, M. P. Chipperfield, K. S. Law, J. A. Pyle, D. E. Shallcross, and K. Y. Wang (1999), Modelling $\mathrm{NO}_{\mathrm{x}}$ from lightning and its impact on global chemical fields, Atmos. Environ., 33, 4477-4493, doi:10.1016/S1352-2310(99) 00190-9.

Sumner, A. L., and P. B. Shepson (1999), Snowpack production of formaldehyde and its effect on the Arctic troposphere, Nature, 398, 230-233, doi:10.1038/18423.

Thonicke, K., I. C. Prentice, and C. Hewitt (2005), Modeling glacialinterglacial changes in global fire regimes and trace gas emissions, Global Biogeochem. Cycles, 19, GB3008, doi:10.1029/2004GB002278.

Tiedtke, M. (1989), A comprehensive mass flux scheme for cumulus parameterization in large-scale models, Mon. Weather Rev., 117, 1779-1800, doi:10.1175/1520-0493(1989)117<1779:ACMFSF $>2.0$. $\mathrm{CO} ; 2$.

Valdes, P. J., D. J. Beerling, and C. E. Johnson (2005), The ice age methane budget, Geophys. Res. Lett., 32, L02704, doi:10.1029/2004GL021004.

Valentin, K. M. (1990), Numerical modelling of the climatological and anthropogenic influences on the chemical composition of the troposphere since the Last Glacial Maximum, Ph.D. thesis, Univ. of Mainz, Mainz, Germany.

Verma, S., O. Boucher, M. S. Reddy, H. C. Upadhyaya, P. Le Van, F. S. Binkowski, and O. P. Sharma (2007), Modeling and analysis of aerosol processes in an interactive chemistry general circulation model, J. Geophys. Res., 112, D03207, doi:10.1029/2005JD006077.

Walton, J. J., M. C. McCracken, and S. J. Ghan (1988), A global scale Lagrangian trace species model of transport, transformation and removal processes, J. Geophys. Res., 93, 8339-8354, doi:10.1029/ JD093iD07p08339.

Wang, K. Y., J. A. Pyle, M. G. Sanderson, and C. Bridgeman (1999), Implementation of a convective atmospheric boundary layer scheme in a tropospheric chemistry transport model, J. Geophys. Res., 104 23,729-23,745, doi:10.1029/1999JD900383.

Warwick, N. J., S. Bekki, K. S. Law, E. G. Nisbet, and J. A. Pyle (2002), The impact of meteorology on the interannual growth rate of atmospheric methane, Geophys. Res. Lett., 29(20), 1947, doi:10.1029/2002GL015282.

Weber, S. L., A. J. Drury, W. H. J. Toonen, and M. van Weele (2010), Wetland methane emissions during the Last Glacial Maximum estimated from PMIP2 simulations: Climate, vegetation, and geographic controls, J. Geophys. Res., 115, D06111, doi:10.1029/2009JD012110.

Wild, O. (2007), Modelling the global tropospheric ozone budget: Exploring the variability in current models, Atmos. Chem. Phys., 7, 2643-2660, doi:10.5194/acp-7-2643-2007.

Wilkinson, M. J., R. K. Monson, N. Trahan, S. Lee, E. Brown, R. B. Jackson, H. W. Polleys, P. A. Fay, and R. Fall (2009), Leaf isoprene emission rate as a function of atmospheric $\mathrm{CO}_{2}$ concentration, Global Change Biol., 15 , 1189-1200, doi:10.1111/j.1365-2486.2008.01803.x.

Yang, X., J. A. Pyle, and R. A. Cox (2008), Sea salt aerosol production and bromine release: Role of snow on sea ice, Geophys. Res. Lett., 35, L16815, doi:10.1029/2008GL034536.

Ziemke, J. R., and S. Chandra (2003), La Niña and El Niño-induced variabilities of ozone in the tropical lower atmosphere during 1970-2001, Geophys. Res. Lett., 30(3), 1142, doi:10.1029/2002GL016387.

G. D. Carver and J. A. Pyle, Centre for Atmospheric Science, Department of Chemistry, University of Cambridge, Cambridge CB2 $1 \mathrm{EW}, \mathrm{UK}$

M. A. Hutterli, TOFWERK AG, Uttigenstrasse 22, CH-3600 Thun, Switzerland.

A. E. Jones, J. G. Levine, and E. W. Wolff, British Antarctic Survey, High Cross, Madingley Road, Cambridge CB3 0ET, UK. (javi@bas.ac.uk)

O. Wild, Lancaster Environment Centre, University of Lancaster, Lancaster, LA1 4YQ, UK. 